\title{
CONTEXTOS FUNERARIOS TARDÍOS EN LA SALINA, VALLE DEL RÍMAC
}

\author{
Marco Antonio Machacuay \\ Rocío Aramburú Casas
}

\begin{abstract}
Sumilla:
Los autores presentan un avance de los resultados de las excavaciones efecturdas en el sitio arqueológico de La Salina en ol actual distrito de El Agustino, en Lima. El área en mención tiene un proceso de desarrollo desde el Periodo Formativo hasta la presencia Inca en el valle. El artículo detalla el uso funerario de las estructuras más tempranas luego de su abandono y se centra en la descripción de un patrón funerario inédito correspondiente al Intermedio Tardio y al Horizonte Tardio en el valle medio del Rimac.
\end{abstract}

\section{Abstract:}

The authors present an advance of the results from the excavations carried out in the archaeological site of La Salina in El Agustino, in Lima. This area has a process of development from the Formative Period until the Inca presence in the valley. The article details the funerary use of the earlier structures after they were left by their owners, and concentrates in the description of an unpublished funerary pattem belonging to the Intermediate Period and Late Horizon in the middle part of the Rimac valley.

\section{INTRODUCCIón}

El área arqueológica de La Salina se ubica en el actual distrito de El Agustino, en la provincia de Lima, en los $12^{\circ} 01^{\prime} 47^{\prime \prime}$ Latitud Sur y $76^{\circ} 57^{\prime} 58^{\prime \prime}$ Longitud Oeste, a una altura de 288 m.s.n.m., en la margen izquierda del río Rímac (Ravines, 1985: 44-45). El sitio en mención corresponde al área donde el curso del río se estrecha más debido a las estribaciones rocosas de los cerros Puruchuco, en la margen izquierda, y Pedreros en la derecha, existiendo entre ambas formaciones geologicas una distancia aproximada de $4 \mathrm{~km}$ (ver fig. 1). Las zonas arqueologicas existentes en la actualidad en esta parte del valle son numerosas. Entre ellas podemos mencionar a Puruchuco, Ceres, Bellavista, Trapiche, Perales, Mayorazgo, Sta. Raquel, Granados y Melgarejo en la margen izquierda y, en la margen derecha a Pedreros y Campoy, abarcando un extenso período de tiempo, desde el Formativo hasta el Horizonte Tardío.

El área arqueológica de La Salina abarca $1 \mathrm{~km}^{2}$ aproximadamente. Corresponde a un conjunto de estructuras entre las que destaca un complejo arquitectónico en forma de U, plataformas cuadrangulares y una serie de montículos diseminados en los alrededores (ver fig. 2).

En el mes de junio de 1996 el Instituto Nacional de Cultura efectuó trabajos de prospección en el área con el fin de evaluar la zona, para lo cual se excavaron hasta 24 pozos de cateo en igual número de unidades. En una segunda temporada, nos empeñamos en el rescate arqueologico de la Unidad 11, correspondiente a uno de los montículos funerarios, el cual ya presentaba una seria destrucción por el proceso de urbanización del área años atrás. Aquí se efectuó el hallazgo de varios entierros, definiendo las características funerarias particulares de estas estructuras, pertenecientes al Intermedio Tardío, nunca antes registradas.

\section{EXCAVACIONES ENLASALINA}

Los pozos de cateo se ubicaron al sureste del brazo derec ho de la estructura arquitectónica en forma de U, correspondiente al Período Formativo. Se excavaron unidades de un mínimo de $1 \times 2$ metros de lado en las bases de los montículos y alrededores. En el presente artículo nos referimos específicamente a la descripción de contextos funerarios correspondientes a períodos tardíos, no sin antes describir sucintamente las unidades de excavación más importantes relacionadas entre sí por sus características (ver fig. 2).

Las Unidades 3 y 8 se practicaron en áreas planas cercanas a los montículos, pero no presentaron material arqueologico rescatable, considerándoseles sólo como un ejemplo del disturbamiento del área, puesto que en años anteriores se había retirado con palas mecánicas al menos un metro de tierra superficial, para la venta de lotes.

Marco Aneonio Machacuay y Rocto Aramburú Casas. Arquélogos y Candidatos a la Maestría en Arqueología Andina: Mención en Manejo de Sitios Monumentales, por la Universidad Nacional Mayor de San Marcos, Lima. 


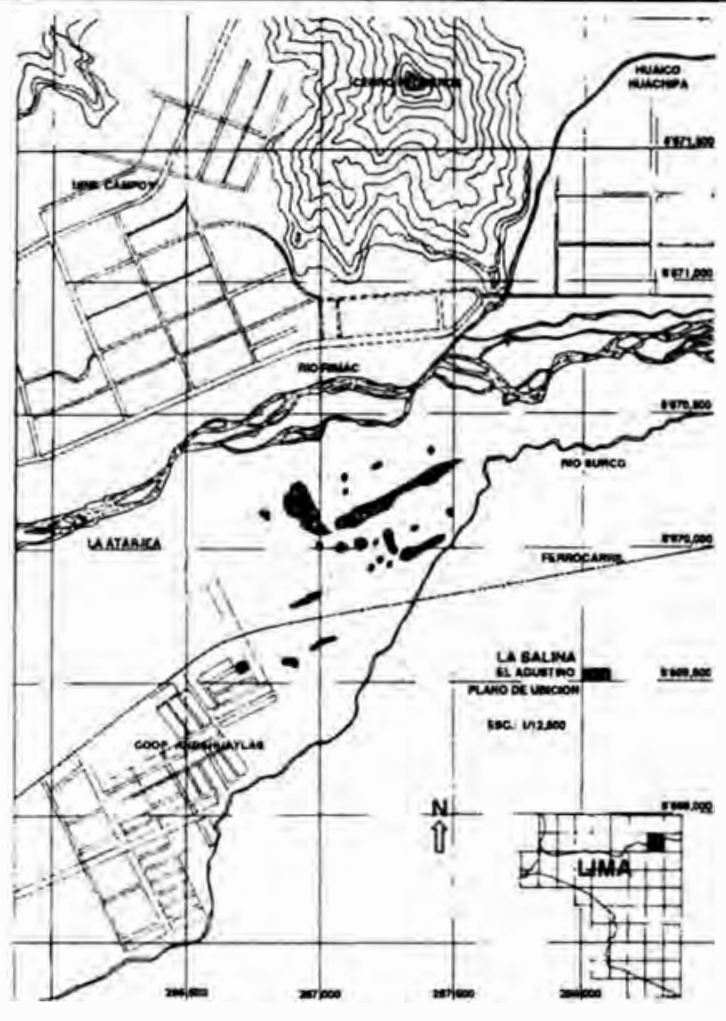

Fig. I Mapa de Ubicación.

Las Unidades 5,7 y 15 se excavaron en estructuras que, por los elementos arquitectónicos, pueden estar relacionadas a la estructura en forma de $U$. La Unidad 5 se practicó al pie de uno de los montículos disturbados que no presentaba una forma arquitectónica definida que indicaría su naturaleza. En esta oportunidad, a pocos centímetros de la superficie, se ubicaron muros ciclópeos, a manera de cimientos, que pueden corresponder a la estructura derruida de la superficie. Estos muros se componían de guijarros de grandes dimensiones, perfectamente alineados y con una cara plana, unidos entre sí por arcilla. La dirección era la misma que la de la estructura en forma de U. No se encontraron fragmentos de cerámica. Las Unidades 7 y 7 a se efectuaron en una estructura de planta cuadrangular y elevación trapezoidal. Estaba conformada por hileras de guijarros de medianas dimensiones, separadas entre sí por capas de tierra arcillosa y colocadas de manera escalonada, lo que le confirió una inclinación determinada a los lados de la estructura. En la Unidad 7 sólo se logró definir los detalles arquitectónicos, muy semejantes a los que después se encontraron en la Unidad 15, mientras que en la Unidad 7a se definió una estructura funeraria correspondiente a una cista construida a base de guijarros unidos con arcilla y con un ligero enlucido interior. Esta cista se practicó excavando un hoyo sobre la estructura cuadrangular original que fue disturbada por éste y otros entierros que en la actualidad se encuentran completamente "huaqueados", como la unidad descrita; sin embargo, al fondo de esta cista se encontró la base del fardo con los huesos del pie del individuo colocados sobre un gran mate relleno de algodón. El fardo, al parecer, fue arrancado desde arriba. La fragmentería cerámica indica que este contexto disturbado corresponde al Horizonte Tardío. La Unidad 15 corresponde a uno de los brazos de una estructura en forma de $L$ que sigue el mismo alineamiento de la estructura en forma de $U$, y que junto al de las Unidades 7 y 5 formarían parte del conjunto del Período Formativo del área. Posteriormente, en perfiles observados en zonas disturbadas del brazo derecho de la estructura en $U$, pudimos observar detalles arquitectónicos semejantes a los de las unidades trabajadas, sin embargo, en todas se presenta una ausencia de material cerámico diagnóstico. Estas estructuras fueron usadas masivamente con fines funerarios durante los períodos tardíos.

La Unidad 22 se practicó en lo que podría ser una plaza, delimitada por el montículo en forma de L, a escasos metros y frente al montículo principal. En un pozo de $1 \times 2$ metros de lado excavamos hasta 1 metro y medio de profundidad y pudimos definir una superficie de usoconformada por un empedrado de pequeños guijarros, enteros y fraccionados, asociados a cenizas y fragmentos de cerámica doméstica correspondientes al Formativo Tardío del valle. Esta superficie se asentaba directamente sobre terreno estéril y es también un ejemplo de todo el registro que se ha perdido por la extracción de tierra arcillosa para su comercialización. Lamentablemente, meses después de acercarnos al lugar pudimos descubrir

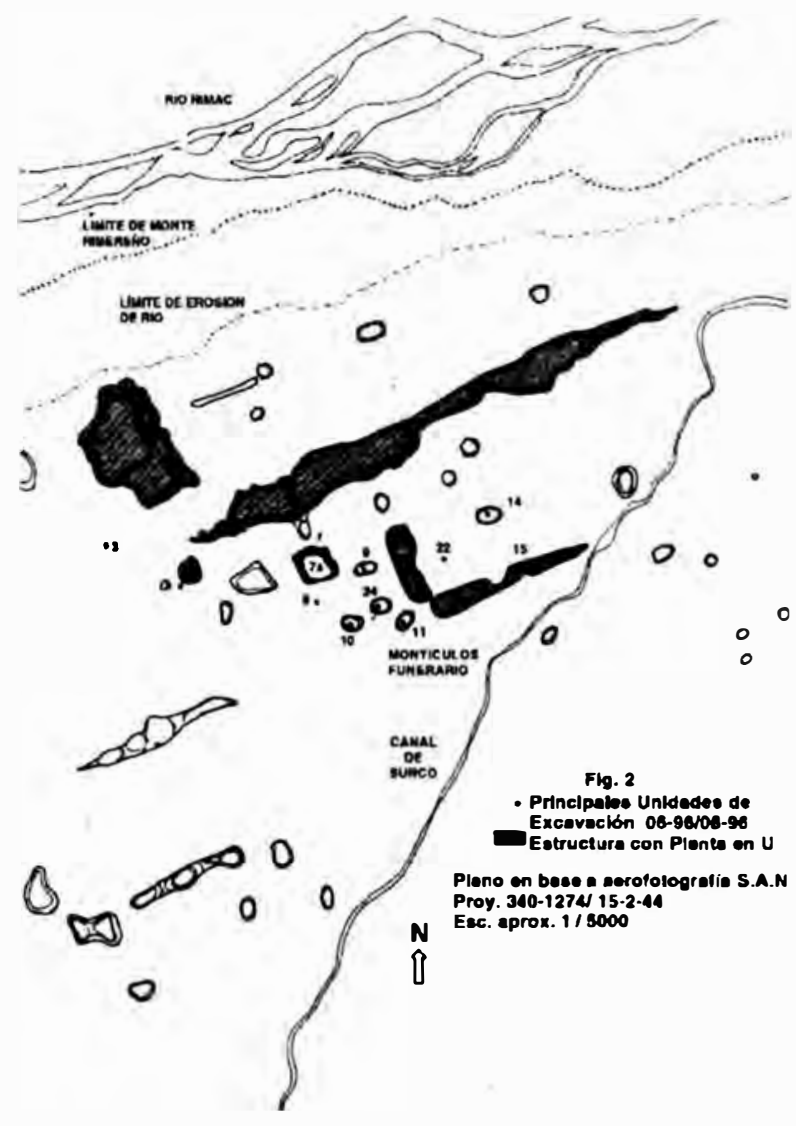

Fig. 2. Área Arqueológica de La Salina. 
que éste había sido completamente arrasado, intencionalmente.

Las Unidades 10 y 14 corresponden a estructuras que presentan un muro de guijarros unidos con argamasa, con una superficie exterior plana. La Unidad 10 tenía una planta cuadrangular de esquinas curvas. El muro no tenía más de 1 metro de alto en ambos casos. Estas estructuras, que no podemos ubicar cronológicamente, recibieron posteriormente el mismo tratamiento de los montículos funerarios tardíos al ser cubiertas con rellenos de guijarros. Al interior de la Unidad 10 se presentó una ofrenda y un entierro de niño correspondientes al Horizonte Tardío, así como cistas disturbadas semejantes a las cistas de la Unidad 7. Posiblemente las estructuras cubiertas correspondan a períodos más tempranos de la historia del lugar.

Las Unidades 4 y 9 corresponden a estructuras que, al parecer, fueron construidas durante el Intermedio Tardío y que se caracterizan por haber sido levantadas a base de acomodamientos circulares de guijarros de medianas y pequeñas dimensiones, a manera de muros de contención de rellenos de guijarros más pequeños. Estos fueron mezclados con tierra arcillosa y algo de basura, entre la que se pudo rescatar fragmentos de cerámica del Período Formativo, Intermedio Temprano, Horizonte Medio e Intermedio Tardío. Entre el disturbamiento se encontraron restos de entierros disturbados, correspondientes a los períodos tardíos. En la excavación de ambas unidades no se pudo hallar contextos funerarios intactos o algún tipo de ofrenda. Hay que indicar que estos montículos son los más pequeños del área, en todas sus dimensiones.

Las Unidades 11 y 24 corresponden a los montículos funerarios más elaborados del Intermedio Tardío; ambos son idénticos en estructura arquitectónica y en el material funerario. En la Unidad 24 sólo se practicó una trinchera de 2 metros de ancho que se extendía desde la base del montículo hasta su cima. En este caso, sólo se efectuó un descombramiento o retiro de las capas superficiales y el primer relleno, dejando a la vista toda la estratigrafía del montículo. En esta etapa del trabajo las excavaciones se detuvieron.

A continuación, pasamos a describir detalladamente los contextos funerarios más importantes, especialmente los de la Unidad 11, por ser el único montículo en el que éstos se excavaron completamente, del total de 11 unidades.

\section{CONTEXTOS FUNERARIOS TARDÍOS}

\section{Unidad 11 : Montículo Funerario Tardio}

Se trata de un montículo ubicado sobre terreno de cultivo en el extremo sur de la zona investigada (ver figs. 2-6 y 10), inmediato a una carretera afirmada moderna.

El montículo ha sufrido un fuerte disturbamiento, por lo menos en más del $50 \%$, en sus lados sur y este, por pala mecánica. Los vecinos del lugar refieren que éste se produjo añcs atrás por la instalación de tuberías de agua y postes de alta tensión. En la actualidad, lo que queda del montículo conserva una forma oval alargada en dirección norte $35^{\circ}$ este, tomada en su eje central. La cumbre del montículo se levanta aproximadamente a $2 \mathrm{~m}$ de la superficie. En los lados disturbados sur y este no se aprecia ningún tipo de estructuras, sólo rellenos de guijarros de medianas y pequeñas dimensiones, mezclados con tierra polvorienta y arcillosa en los que se encuentra fragmentos de cerámica y restos vegetales. Hacia los lados norte y noreste se aprecia una pendiente de aproximadamente $45^{\circ}$, con la mismas características de material.

\section{Capa 1:}

Consta de cantos rodados de variados tamaños mezclados con tierra arcillosa y polvorienta, presencia de basura moderna y regular cantidad de cerámica algo erosionada; la superficie se presenta en pendiente descendente hacia el norte. En esta dirección, hacia la base de los escombros, se presenta una mayor cantidad de tierra arcillosa, que son los restos del terreno de cultivo original, sobre la cual ha crecido grama. Estos vegetales se han introducido entre las piedras de los escombros.

Es preciso acotar que la separación entre esta capa y la siguiente es muy insegura debido a las características de los componentes y al disturbamiento presente en todo el montículo. Asimismo, es relativo su grosor.

Se diferencian al menos dos momentos de deposición de formación de escombros (1a y $1 \mathrm{~b}$, ver fig. 6), la más profunda, y por ende la más cercana a la base del montículo, presenta una mayor cantidad de cantos rodados de grandes y medianas dimensiones, todo lo contrario hacia la superficie, donde hay guijarros y mayor cantidad de tierra.

\section{Capa 2: Relleno 1.}

Se presenta sobre todo en la cima, hacia la pendiente del montículo desaparece por disturbamiento, no existiendo ningún muro que la contenga y se encuentra depositada sobre un sello de arcilla (Capa 3). Esta capa se encuentra asociada a las estructuras funerarias presentes en la cumbre del montículo; se compone de cantos rodados de variados tamaños, mezclados con tierra arcillosa polvorienta; entre este material se puede encontrar algunos fragmentos de cerámica y vegetales como cáscaras de maní, maíz y hojas de pacae. Usualmente, presenta grumos de arcilla y algo de fragmentos de argamasa, tanto suelta como en su deposición original, entre las piedras. Esta característica se hace más obvia al estar próxima alguna estructura, de tal manera que no existe ninguna separación precisa entre 


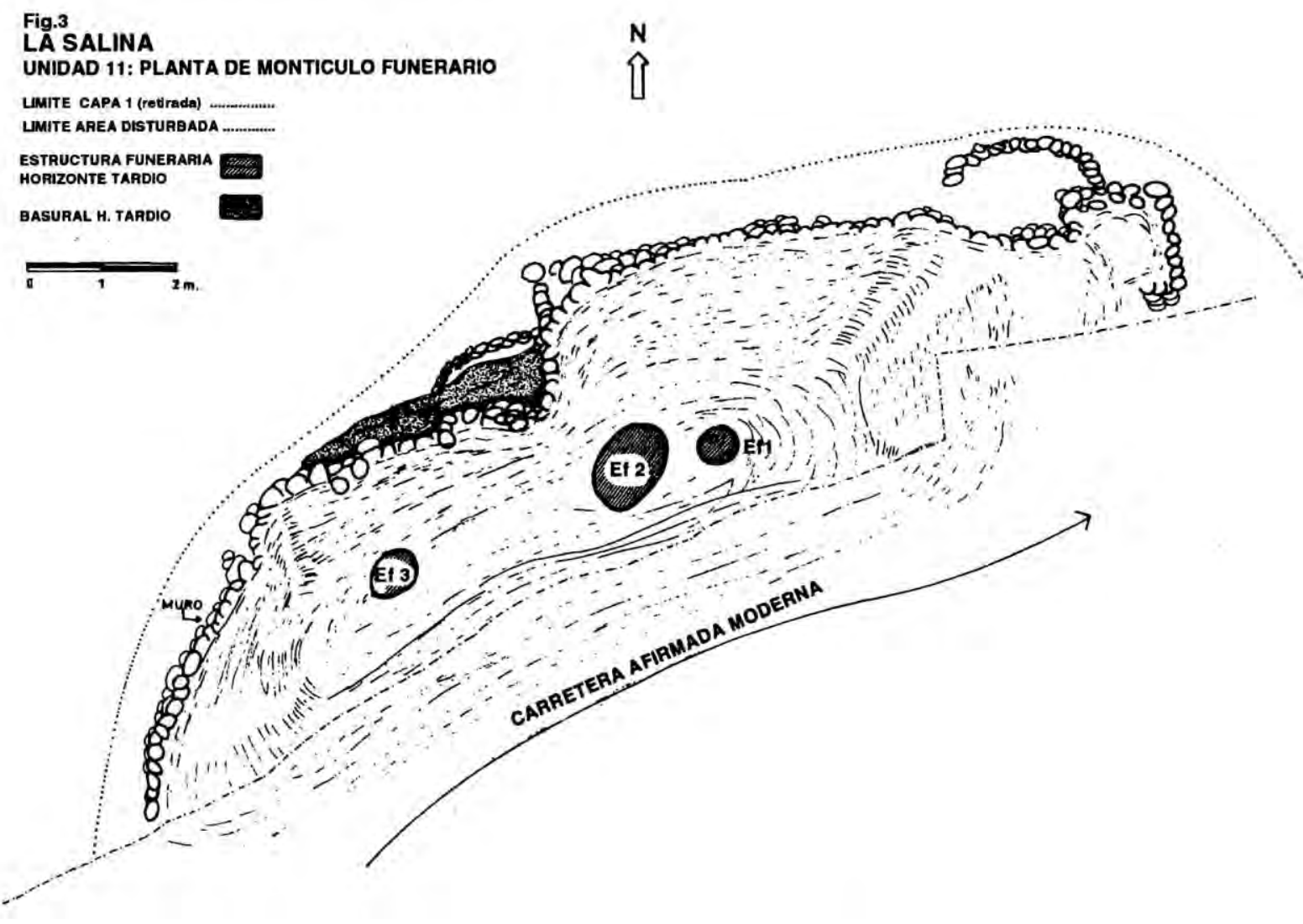

Fig. 4

LA SALINA

UNIDAD 11 : CONTEXTOS FUNERARIOS,I. TARDIO

CORTE

SELLO DE ARCILLA ….........

NUMERO DE CAPA 1,23 etc.

AREA DISTUR BADA …......

CONTEX TO FUNERARIO VUIIIIT

HALLAZGO

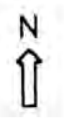

$\Uparrow$
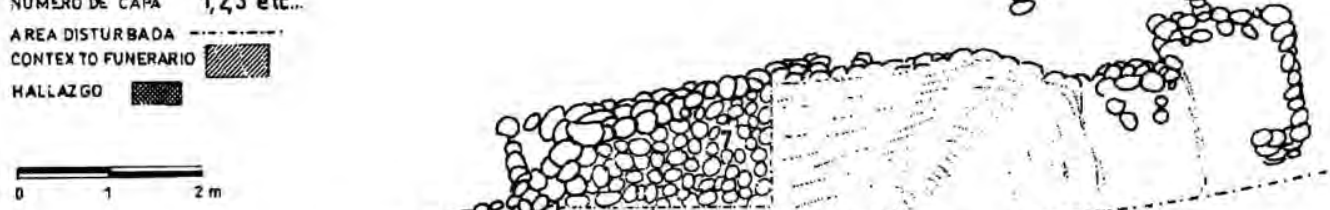
la misma estructura y el relleno que la contiene. La colocación de las piedras ha sido, en algunos casos, algo ordenada y en otros no. La presencia de material cultural es escasa, distinguiéndose a primera vista material Inca asociado. El disturbamiento dificulta la seguridad de esto, pues los materiales se deslizan a través de las rendijas de los cantos rodados; por otro lado, se presentan evidencias de roedores y reptiles de los que se encuentran restos de sus cuerpos y nidos.

\section{Capa 3: Sello de Arcilla 1.}

Al igual que la capa anterior, sólo se conserva en la parte superior del montículo y sólo en la cuadrícula 11B, en su mínima expresión. Está conformada por una masa de arcilla de 4 a $5 \mathrm{~cm}$ de espesor, bastante pura y colocada inmediatamente sobre un relleno de guijarros (Capa 4), lo que la hace bastante frágil e irregular. Se aprecia que para dar una superficie uniforme y una mejor base al piso se ha agregado algo de cascajo y piedras menudas para cubrir las ranuras dejadas por los cantos rodados al ser amontonados. Definitivamente no es un piso por la fragilidad que lo caracteriza. Este sello de arcilla se encuentra asociado a la mayoría de los Contextos Funerarios, con excepción del 10 y 11 que se encontraban por debajo de este nivel (ver figs. 4 y 6 ).

\section{Capa 4: Relleno 2.}

Este relleno está conformado básicamente por cantos rodados de medianas y pequeñas dimensiones, sueltos y mezclados con tierra arcillosa polvorienta y algo de arena; también se presentan pequeños lentes de basura y material orgánico suelto (maíz, frijoles, algodón, lúcuma, pacae, etc). Tiene un espesor de aprox. 20 a 30 cm y se encuentra sobre el sello de arcilla 2 (ver figs. 4 y 6 ).

\section{Capa 5: Sello de Arcilla 2.}

Está conformada por una masa de arcilla de 4 a $5 \mathrm{~cm}$ de espesor, bastante pura y colocada directamente sobre el relleno inferior de la Capa 6, lo que la hace bastante frágil e irregular, con idénticas características a la ya descrita. Se ha conservado sólo en el extremo este del montículo y en su parte central, al sur del montículo, se presentan algunas huellas de ceniza e ignición sobre este sello, sin apreciarse algún material orgánico definido en estas cenizas; los únicos contextos funerarios asociados a este sello son el 10 y el 11 (ver figs. 5 y 6 ).

\section{Capa 6: Relleno 3.}

De las mismas caracteristicas de los rellenos anteriores; conformado por tierrra arcillosa y arena mezclada con basura orgánica en pequeñas cantidades y escasa cantidad de fragmentería de cerámica; tiene un espesor de aproximadamente 30 a $40 \mathrm{~cm}$; se encuentra depositado inmediatamente sobre los cantos rodados pircados que conforman la base del montículo. Mucho de este relleno se ha deslizado entre las grandes rendijas que dejan entre sí los enormes cantos rodados que conforman la siguiente capa (ver figs. 5 y 6 ).

\section{Capa 7: Base del Montículo.}

Está conformada completamente por el alineamiento irregular de guijarros de grandes y medianas dimensiones que van a dar forma al montículo central. En este acomodamiento de guijarros se puede diferenciar alineamientos principales que van a servir como muros de contención cuya dirección es, aproximadamente, de suroeste a noreste y de noroeste a sureste. Los principales de ellos han sido señalados en el dibujo de planta (ver fig. 5). El tamaño de los guijarros deja ranuras bastante amplias entre ellos. Entre muro y muro podemos apreciar un acomodamiento ligero del mismo material, pero de pequeñas dimensiones, lo cual permite que se deslice entre las ranuras. Estas alineaciones de grandes guijarros no obedecen a una planificación preconcebida, lo que se constata por la forma irregular con la cual se han elaborado. Es frecuente encontrar muros acoplados, extensos y aislados; aún así podemos definir un crecimiento desde el núcleo a la periferia y, más profusamente, de este a oeste. Creemos que la cista del Contexto Funerario 10 forma parte de esta misma capa y el acomodamiento inicial de los muros debe dar origen al núcleo del montículo.

\section{Basural del Horizonte Tardío:}

Se encuentra depositado entre el muro periférico del montículo y uno más pequeño levantado exprofesamente para este fin. Básicamente, podemos definir dos $\epsilon$ lementos: tierra arcillosa con cantos rodados y lentes de material orgánico con abundancia de restos vegetales, tales como cañas, pacae, lúcuma, guayaba, maíz, maní y algodón, en frutos, hojas y semillas; además de carbón, cenizas, huesos de camélidos y muchos fragmentos de cerámica. No se encontró restos de moluscos. En este relleno se registraron los mejores fragmentos diagnósticos relacionados a la cerámica tardía local de la ocupación Inca. Los lentes de basura y los escombros que se intercalan tienen una inclinación de sureste a noreste. De los árboles frutales hay ramas enteras, junto a hojarasca, que parece el resultado de una poda. De los demás cultivos, al parecer serían los restos de las cosechas. Algunos tallos de los arbustos estaban algo trabajados. Hay huellas de ignición indicando que quemaron algo de la hojarasca de la basura, En el muro perimétrico sobre cuya cara y base se depositó este relleno se han preservado restos de argamasa, lo que evidencia la perpetuidad de este relleno desde su colocación por lo menos 500 años atrás. Esta asociado a la Capa 2 (ver fig. 3 y 6 ).

\section{Hallazgo 1: Cista con Ofrendas.}

Se ubicó inmediatamente próximo al este de la Estructura Funeraria 1. Su forma es ligeramente circular pero irregular e igual a las demás estructuras. Está conformado en su totalidad por cantos rodados de dimensiones variadas, alternados en hileras, sin más ordenamiento que un inestable acomodamiento que se va estrechando en su parte superior hasta formar una 
ligera bóveda. Sus dimensiones aproximadas son de 50 $\mathrm{cm}$ en su diámetro inferior, $80 \mathrm{~cm}$ en su diámetro medio, $50 \mathrm{~cm}$ en el superior y una altura aproximada de $90 \mathrm{~cm}$. Esta ofrenda está relacionada al Sello de Arcilla 1, descartándose que sea intrusiva a la construcción de los primeros niveles. La ofrenda depositada consistía en una bolsa de tejido llano de algodón blanco y pardo, en cuyo interior se colocaron mazorcas de maíz. Esta bolsa se encontraba sujeta a mates perforados en sus bordes y unidos a la bolsa por medio de hilos de algodón y cuerdas de junco (ver fig. 11). Uno de los mates de forma expandida se encontraba sobre esta bolsa y otro, de dimensiones más pequeñas, se encontraba a un costado; a su vez, este grupo se encontraba unido por cuerdas de juncos a una olla doméstica (ver fig. 9 a).

La cuerda de junco bordeaba la vasija y sujetaba las asas de las mismas; esta vasija contenía gran cantidad de maíz. También se encontraron algunas semillas de frijoles pero, al parecer, su presencia es incidental por el relleno de la cista. Estos objetos principales se encontraban en la parte central de la base de la cista estando la bolsa y los mates al extremo norte y la vasija al extremo sur. Luego de ser colocados estos objetos fueron cubiertos por algodón pardo y blanco sin cardar e inmediatamente sobre estos se colocaron mates de variadas dimensiones, volviéndose a cubrir con nuevas capas de algodón y tierra. Estos mates tienen huellas de haber contenido material orgánico en estado líquido y en uno se presentaron huesos de cuy. Al menos se colocaron 5 troncos en diferentes niveles, hasta la parte superior de la cista, siendo su función, al igual que el algodón, la de disminuir la presión del relleno de tierra y guijarros sobre las ofrendas. El contenido orgánico de la cista se encontraba disturbado por la actividad de los roedores y reptiles.

\section{Estructuras Funerarias 1 y 3:}

Ambas se presentan disturbadas y relacionadas al último relleno en la cima del montículo. Son estructuras de forma circular de las cuales sólo se conserva la base. Los lados de estas estructuras se han elaborado consolidando el mismo material de relleno (Capa 2) con argamasa; asimismo, se ha utilizado como base el sello de arcilla siguiente (Capa 3). No son estructuras muy bien definidas, pero por su tamaño debieron ser de niños o algún depositario de ofrendas. Se encontraron cubiertas con la capa superficial (ver figs. 3 y 6 ).

\section{Estructura Funeraria 2:}

Es una estructura funeraria disturbada conformada por guijarros unidos con arcilla y a la cual se le ha dado un ligero enlucido interno. Está contenida dentro de la Capa 2 y separada de la Capa 3 (Sello de Arcilla) por los mismos materiales que la conforman. En su forma es bastante irregular, casi ovalada, con un eje sureste-noreste. Los cantos rodados no tienen un tamaño regular y en general, no se podría diferenciar entre el relleno y las mismas paredes de la matriz de no ser por el enlucido. De estas paredes, la mejor conservada se halla al suroeste. La unión entre estas paredes y el sello de arcilla que conforma el piso es de forma redondeada; la argamasa del piso es de 2 a $3 \mathrm{~cm}$ de grosor, encontrándose destruido en su mayor parte.

Hacia el centro se logró ubicar la impronta de la base del fardo y los restos de su ajuar funerario, tales como vasijas y semillas, lo que nos permite ubicarlo en el Horizonte Tardío. Esta estructura ayudó a definir la situación crunológica acerca del uso del montículo pues parte de ella se encontraba sobre un entierro Ichma, correspondiente al Intermedio Tardío (Contexto Funerario 4), así como su relación con el último relleno y el basural, en la base norte del montículo, el cual corresponde a la presencia Inca en el área.

\section{Contexto Funerario 4:}

Se trata de un entierro ubicado al mismo nivel del Sello de Arcilla 1 y en parte cubierto por él. Esta cista presenta una matriz de forma circular de $45 \mathrm{~cm}$ de diámetro y $55 \mathrm{~cm}$ de profundidad, construida a base de cantos rodados de medianas y grandes dimensiones. Las formas más pequeñas de cantos conforman las paredes de la cista, en tanto que las más grandes conforman la penúltima hilera y sobresalen hacia el centro de la circunferencia para sostener las que se sitúan, a manera de cubierta, semejando una falsa bóveda. Por estas particularidades esta cista se diferencia notablemente del relleno que la rodea (Capa 4). El fardo es de forma casi esférica y contiene el cuerpo de un infante envuelto en telas llanas bastante deterioradas. Se encontraba apoyado hacia el noroeste de la pared; en su base se sostenía por algunos guijarros, luego se consolidó su estabilidad con rellenos de tierra. Hacia el ángulo opuesto se encontraba una pequeña olla de cuerpo globular, cuello corto recto, asas tubulares verticales uniendo el cuello y el hombro de la vasija, sin ninguna decoración, con huellas de uso doméstíco y con una soguilla de junco amarrada a las asas, uniéndose en sus extremos por varios nudos; a su lado, algunos centímetros más abajo, se encontró un mate en posición vertical. El contenido del mate no se encontró, pero la olla contenía mazorcas de maíz y semillas de algodón. El fardo se encuentra bastante deteriorado por la acción de los roedores; sin embargo, la cista estuvo bastante bien constituida no dejando pasar tierra a su interior. Sobre las telas superficiales del fardo se encontraba una aguja de madera, con un tortero del mismo material, usada para el hilvanado de algodón (ver fig. 4).

\section{Contexto Funerario 5:}

En este caso, el fardo ha sido acomodado mirando hacia el norte, en un hoyo practicado al interior del relleno (Capa 4) que cubre el Sello de Arcilla (Capa 5) y corresponje a un niño. El corte transversal del fardo es casi rectangular. Al parecer, el cuerpo está en posición flexionada y sostenido con cañas al interior. Todo el conjunto se halla envuelto con telas y rodeado por una 


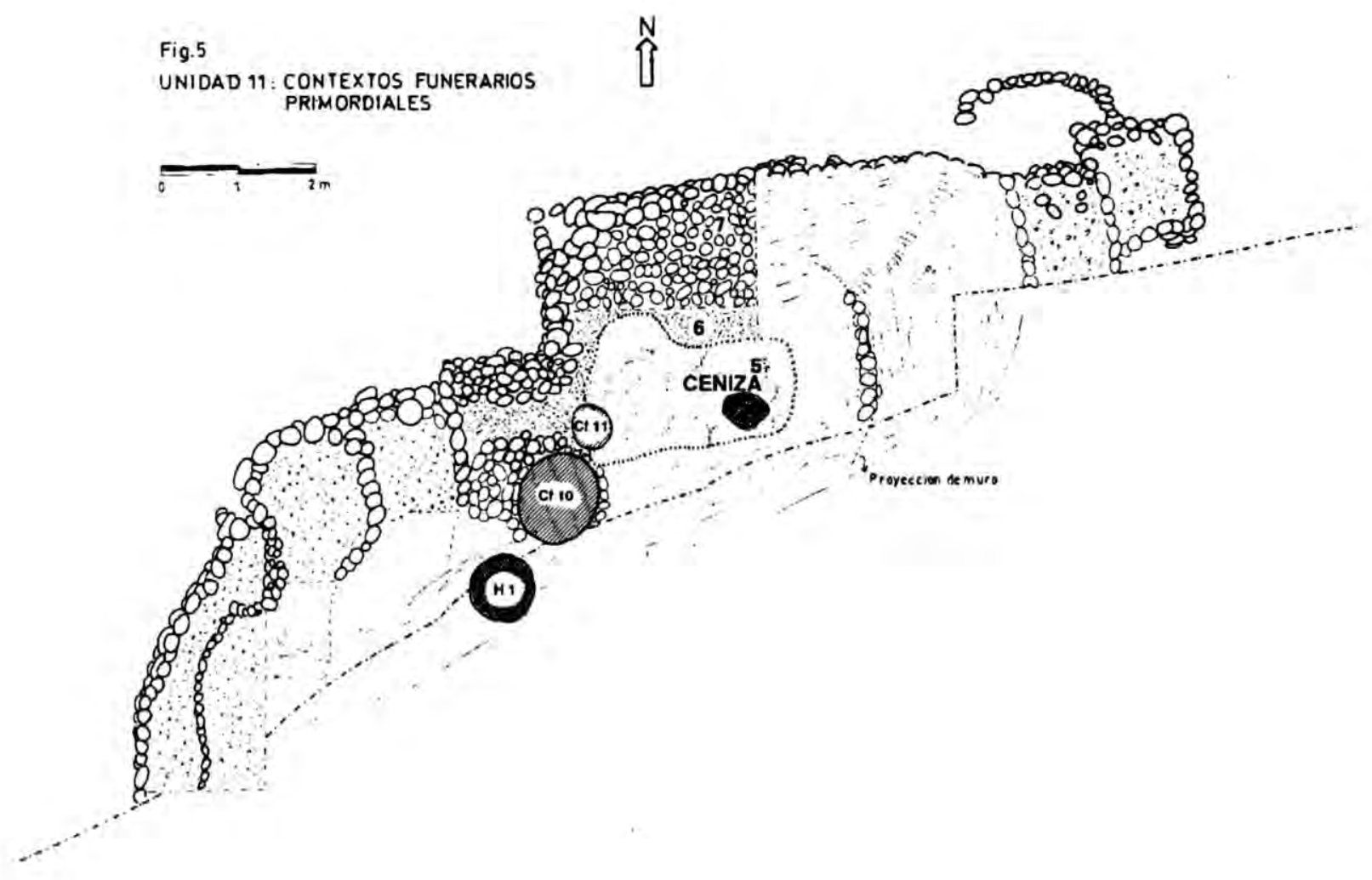

Fig. 6

UNIDAD 11 : CORTE NORTE-SUR DE

ESC: $1 / 25$ MONTICULO FUNERARIO
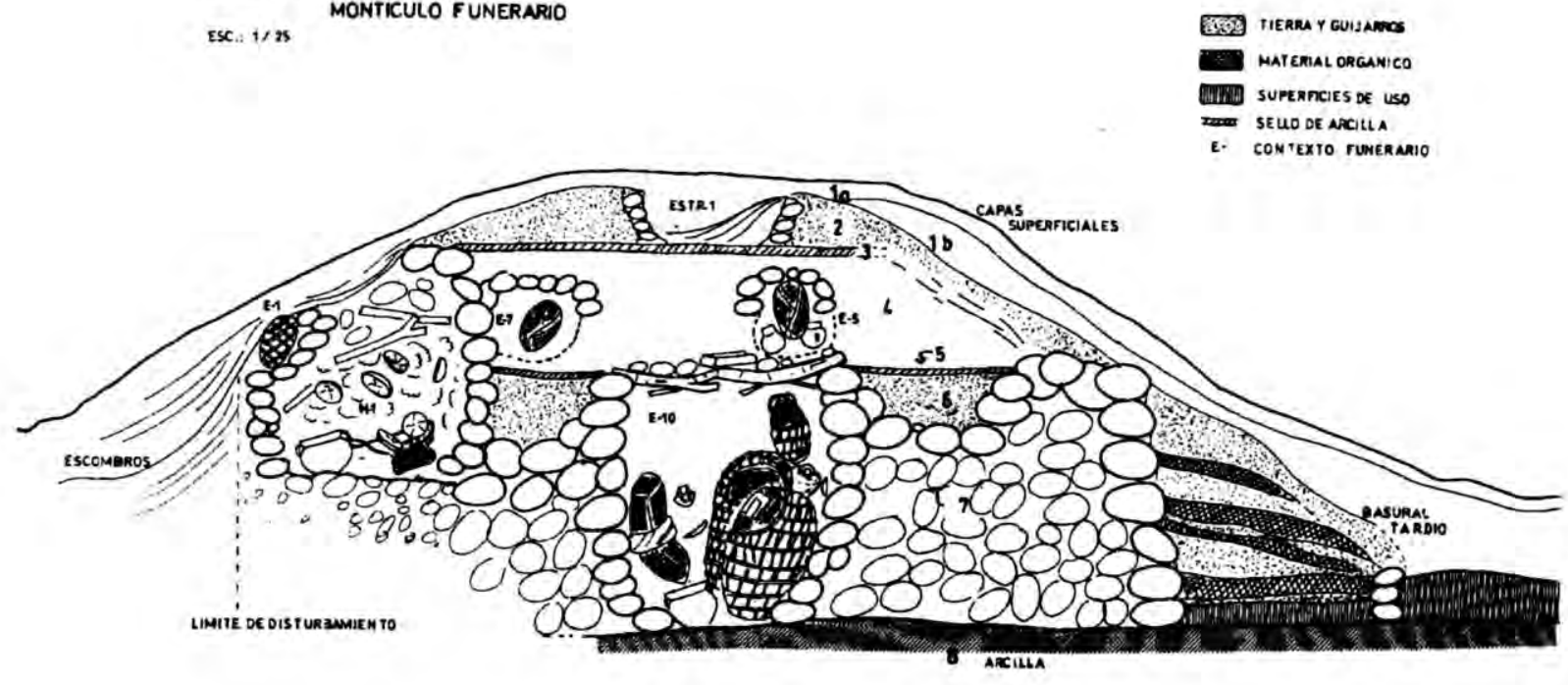
soguilla de junco. El fardo se encuentra algo deteriorado en su parte superior. Luego de acomodarlo, se colocaron vasijas a sus costados; una de las cuales, próxima a la parte delantera del fardo, es una olla de cuerpo globular, base plana, sin cuello y sin asas, con un pulido fino en el que aún se aprecian las huellas del pulidor, sin decoración adicional. Al interior, presento una gran cantidad de maíz, cáscaras de pacae, fragmentos de semillas de canavalia, huesos de roedores, semillas de algodón y un mate colocado a manera de tapa y cuyo contenido se ha deteriorado (fig. $7 \mathrm{c}$ ). Otra vasija es una olla de cuerpo globular y base cónica, de cuello corto recto y divergente, presenta asas planas pequeñas y horizontales sobre sus hombros. Sólo se conserva un fragmento de borde, es burda y está cubierta con hollín en la superficie externa; para hacer la base se ha usado un molde, luego le han agregado la parte superior de manera modelada, en tiras continuas unidas de manera circular. Contenía tierra compacta con material orgánico descompuesto, además de tierra suelta en la que se pudo apreciar, a simple vista, un trozo de madera tubular deteriorado, corontas de maíz, un cráneo de cuy, cáscaras de maní, fragmentos de carbón y algodón. La tierra compacta tenía abundantes cáscaras de maníes en su interior. Se la colocó a un costado del fardo (fig. 7 a). La tercera vasija es un cántaro de cuerpo lenticular y base cónica, de cuello corto recto, asas semi planas verticales en la parte superior del cuerpo, sin decoración; los bordes están deteriorados y presenta huellas de hollín. Al interior no presentaba nada, pero la boca se encontraba cubierta con un manojo de panca. En la tierra suelta del interior se encontró cáscaras de maní y una soguilla de totora (ver fig. 7 b).

\section{Contexto Funerario 6:}

Al parecer corresponde al fardo de un adulto. El corte transversal del fardo es casi rectangular. Sus medidas son $30 \mathrm{~cm}$ de ancho, $41 \mathrm{~cm}$ de largo y $60 \mathrm{~cm}$ de alto. En general, su conservación es muy precaria y la base se encuentra deteriorada por la humedad, lo que nos permite detallar algunos de los elementos de su constitución. El cuerpo está sentado sobre un mate de grandes dimensiones, en cuyo interior se presentan materiales orgánicos descompuestos; se han acondicionado cañas al interior del fardo para sostener el cuerpo y todo el conjunto se halla envuelto con telas. Exteriormente sólo se presentan unas soguillas de junco amarradas alrededor de la parte superior del fardo. Adicionalmente, se encontró una esterilla de junco en la parte superior e inferior del fardo que cubría todo un lado del cuerpo. El entierro no presenta una matriz definida, pero tampoco se aprecia un disturbamiento en el sello de arcilla o en el relleno que lo cubre. El fardo se encontraba mirando al sureste y a sus pies se encontraron tres vasijas y un mate.

La primera de estas vasijas es un cántaro de cuerpo globular, cuello corto recto y con asas tubulares y horizontales en el hombro de la vasija. El borde se encuentra bastante deteriorado, presentando hollín hasta

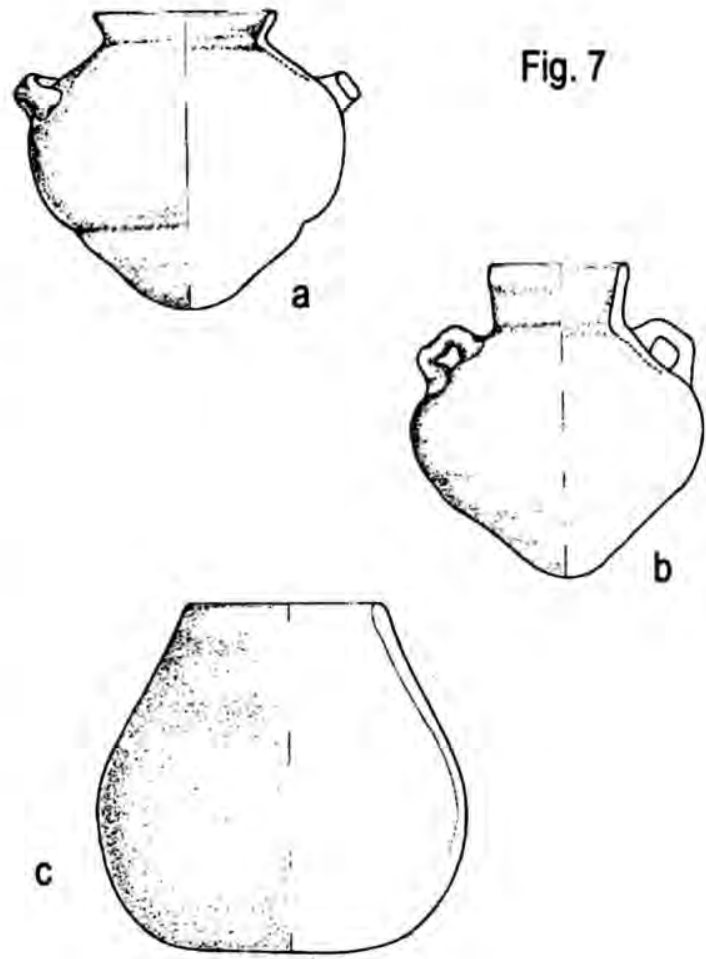

la mitad del cuerpo. Presenta tierra pegada a la boca de la vasija, así como fragmentos de telas que, al parecer, formaron parte de su cubierta (ver fig. $8 \mathrm{~b}$ ). Las otras vasijas son un par de ollas bastantes diferenciadas. La primera de ellas es de cuerpo globular, cuello alto y recto con bordes evertidos, asas tubulares horizontales en la parte superior del cuerpo y está completamente cubierta de hollín. Al interior se pudo encontrar restos de maíz y semillas de algodón, formando una masa compacta con huellas de descomposición in situ. También se presentan fragmentos de mate, probablemente de la tapa que se ha descompuesto totalmente, y ovillos de hilos que han caído al interior, compactándose con todo el contenido (ver fig. $8 \mathrm{c}$ ).

La última vasija es una olla de cuerpo globular, sin cuello y sin asas, que presenta decoración con pintura blanca alrededor del borde. Al interior se pudo encontrar restos de náíz y semillas de algodón. Se encontraba cubierta con un mate (ver fig. 8 a).

\section{Contexto Funerario 9:}

Corresponde al fardo de un adulto colocado al interior del Relleno 2, sin presentar alguna matriz definida o algún acomodo de guijarros que la indiquen (ver fig. 12).

El corte transversal del fardo es casi rectangular. Todo el conjunto se halla envuelto con telas y, adicionalmente, presenta una canastilla de soguillas de junco a manera de red que envuelve toda la parte inferior 


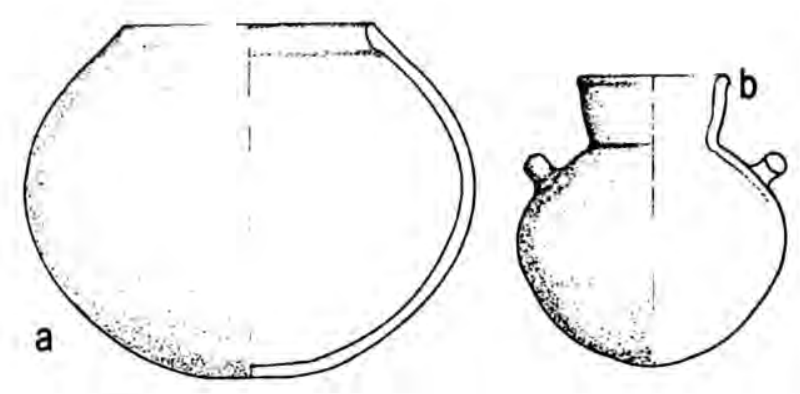

Fig. 8

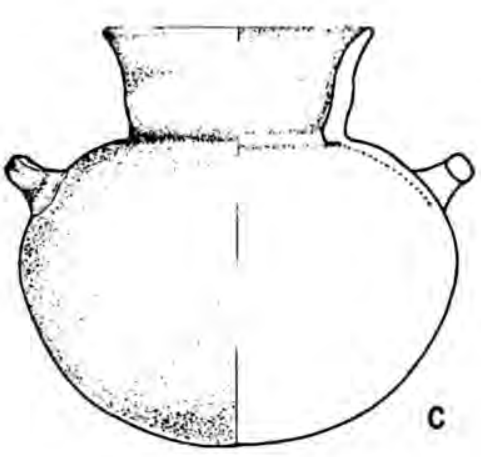

del fardo. La tela superficial que envuelve el fardo se encuentra muy deteriorada por acción de los roedores. Adicionalmente, presenta un cántaro y dos ollas rodeando sus lados.

El cántaro es de forma lenticular, cuello recto y alto, asas semiplanas en la parte media del cuerpo, con engobe rojo oscuro presentando un buen acabado; tiene huellas de hollín en casi todo el cuerpo y la boca ha estado tapada con hojas de carrizo. Al interior no se encontró nada, sólo tierra suelta que ha entrado al romperse la vasija, una bola de arcilla y un fragmento de diente incisivo muy desgastado, que se supone haya pertenecido al entierro.

Las ollas son semejantes, presentan cuerpo globular, cuello corto recto y divergente, asas tubulares verticales uniendo el cuello y los hombros de la vasija. Las dimensiones difieren ligeramente en altura. No hay indicios de cuál es la parte frontal del fardo, aunque por las posiciones de las vasijas nos atrevemos a pensar que se encontraba mirando al Este. Como se puede apreciar en las fotos, es evidente que primero fue colocado el fardo y asegurado en su posición con guijarros y tierra del mismo entorno, luego fueron colocadas las vasijas, una olla a cada lado del fardo y el cántaro delante del mismo. Las ollas fueron cubiertas con mates, en posiciones diferentes, como se puede apreciar en la foto, y el cántaro fue sellado con un atado de pancas de maíz. El contenido de cada olla varía: en una de ellas se encontró una gran cantidad de semillas de algodón y en la otra una gran cantidad de maíz de color morado con huellas de descomposición. Uno de los mates que cubría la vasija tenía huellas interiores de sustancia orgánica descompuesta.

\section{Contexto Funerario 10:}

Es el entierro principal del montículo por estar relacionado directamente a su construcción. En efecto, el montículo fue levantado exprofesamente para contener este entierro. La cista está conformada por el mismo núcleo de la estructura (Capa 7, base del montículo, ver fig. 6), a base de guijarros de medianas y grandes dimensiones, dispuestos irregularmente en forma casi oval, cuyos diámetros alcanzan a medir $1,20 \mathrm{~m}$ y 1,50 $\mathrm{m}$, siendo la profundidad de $1 \mathrm{~m}$ y las paredes casi rectas. La primera fila de guijarros alineados se asienta directamente sobre el terreno arcilloso del área, el cual es muy húmedo, característica que afectó notablemente toda la base del fardo principal, pulverizándola completamente. La matriz era lo bastante amplia para contener dos fardos grandes y cos pequeños acompañados de vasijas de cerámica y mates, con un gran espacio libre entre estos materiales y la cubierta de la entrada. La abertura de la matriz estaba cubierta con guijarros pequeños, tierra, algodón sin cardar y ramas de arbustos sostenidos por troncos de hasta 10 centímetros de diámetro que se entrecruzaban sobre la entrada de la cista. Al parecer,

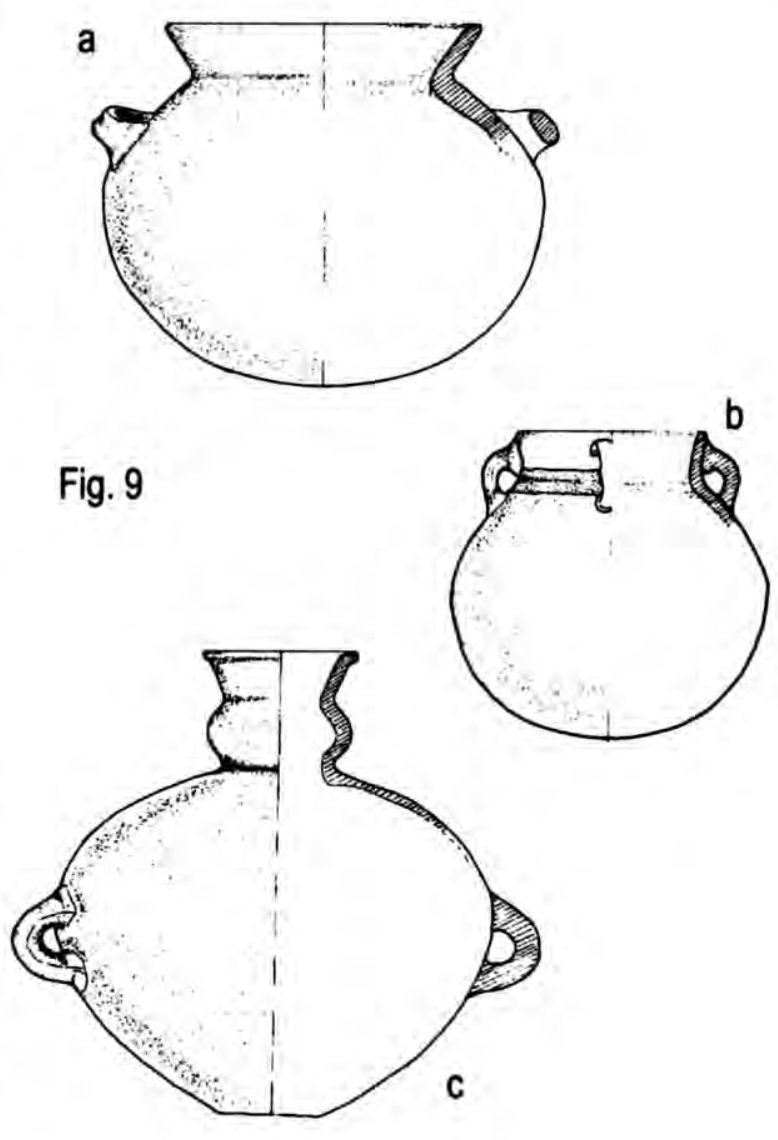




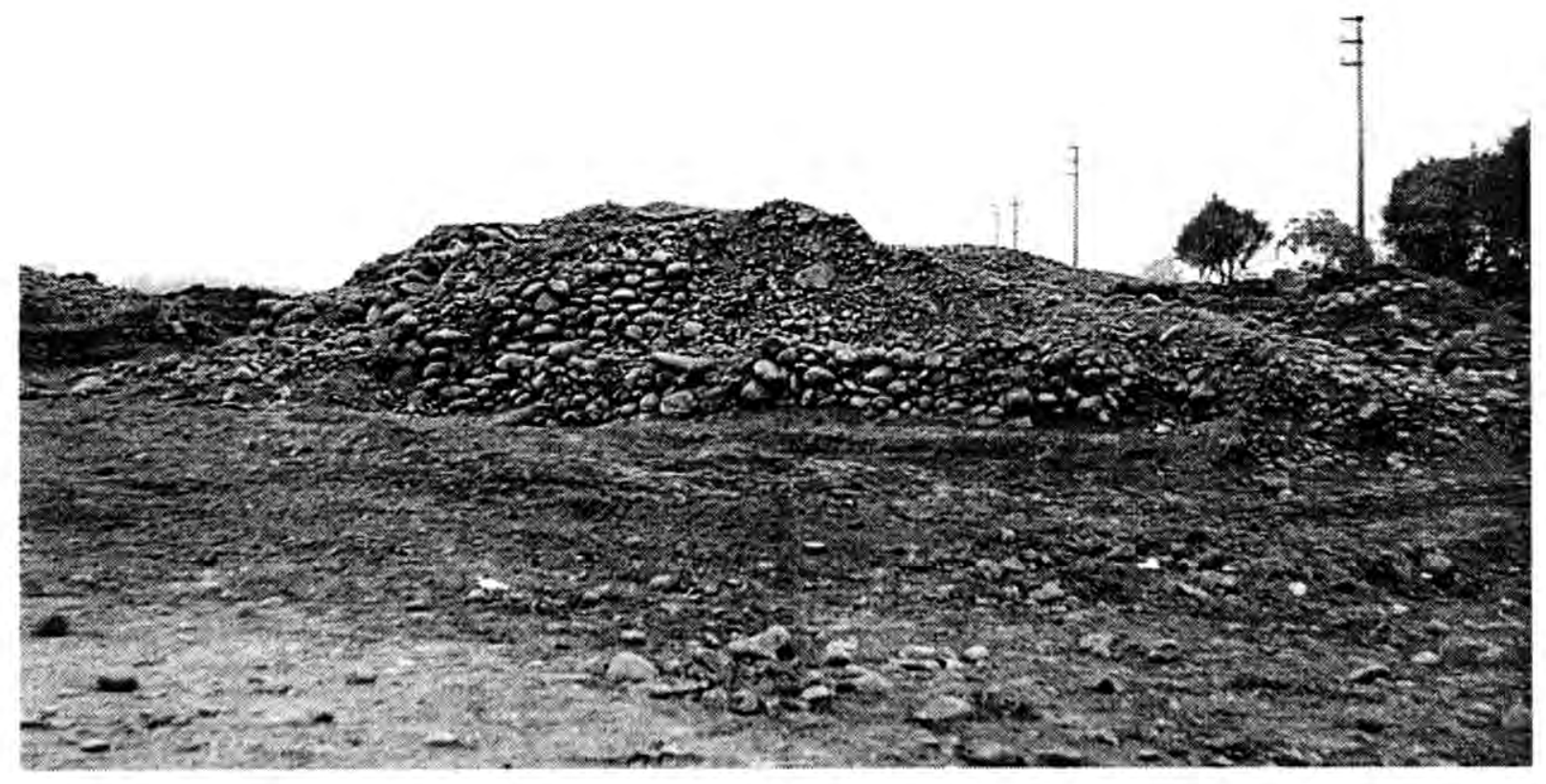

Fig. 10. Unidad 11. Montículo funerario visto desde el noroeste

estos troncos eran ramas de pacae, cuyo deterioro ocasionó que toda la cubierta colapsara cayendo al interior de la cista (ver fig. 13). Cabe destacar la presencia de una sola piedra canteada toscamente en forma de paralelepípedo, procedente de los cerros de los alrededores, que formaba parte de esta cubierta.

$\mathrm{Al}$ interior de la cista se encontraron 4 fardos. El fardo principal corresponde a un adulto al parecer de sexo masculino. El corte transversal del fardo es casi rectangular, guardando su extremo superior una forma casi esférica. El cadáver se halla envuelto con telas y, adicionalmente, presenta una canastilla de soguillas de junco, a manera de red tejida sobre la última envoltura y sostenida a ésta por un ligero hilvanado con hilos. El tejido de esta canastilla no ha sido total, dejando al descubierto una pequeña área en la parte frontal superior del fardo, el cual, a diferencia de otros ejemplares, no presenta pintura. Las medidas del fardo son de $35 \mathrm{~cm}$ de largo por $28 \mathrm{~cm}$ de ancho y $75 \mathrm{~cm}$ de alto. Toda la parte inferior del fardo se perdió irremediablemente al pulverizarse en la extracción de la cista, debido a que fue depositado directamente sobre la arcilla húmeda que forma la base de los montículos. Al interior pudimos observar varias capas de tejidos llanos de algodón, de color blanco y azul, sin ninguna decoración, así como los huesos del cadáver, sostenido por cañas huecas, en posición de cuclillas sobre un gran mate; también se presentaron grandes cantidades de algodón sin cardar y restos de materiales orgánicos descompuestos.
El siguiente fardo es de menores dimensiones. El corte transversal es casi rectangular. Al igual que el fardo anterior, sobre la envoltura de telas se ha tejido una canastilla de totora, pero a diferencia de aquél se ha dibujado en el área libre una $\mathrm{M}$ o $\mathrm{E}$ invertida, como en el fardo del Contexto Funerario 11. La base se encuentra deteriorada afectando la canastilla de totora y la superficie de las envolturas, al parecer debido a los roedores, la humedad y los insectos.

Los otros dos fardos corresponden a infantes que fueron colocados sobre los anteriores y presentan diversas características. El primero de ellos está envuelto íntegramente por telas, colocándosele al final un paño envuelto, a manera de cinta, alrededor de su parte media. $\mathrm{Al}$ parecer, el cadáver se encuentra en forma extendida. El último fardo tiene forma cónica y está envuelto en telas, presentando la canastilla de soguillas de junco a manera de red y dejando abierta toda su parte superior. Sus medidas son $35 \mathrm{~cm}$ de alto por $29 \mathrm{~cm}$ de diámetro. Se encuentr $\lambda$ deteriorado en la parte superior.

Acompañando a los fardos se presentan vasijas dejadas como ofrendas, siendo dos de ellas cántaros, tres ollas y cuatro mates en diferentes lugares.

Uno de los cántaros es de cuerpo lenticular, base cónica, cuello corto y recto, sin ninguna decoración. El otro es mucho más pequeño y modelado de tal manera que se asemeja a un fruto, el cuello es recto y de bordes ligeramente evertidos; presenta un par de asas trenzadas, entre la parte superior del cuerpo y la parte media del 


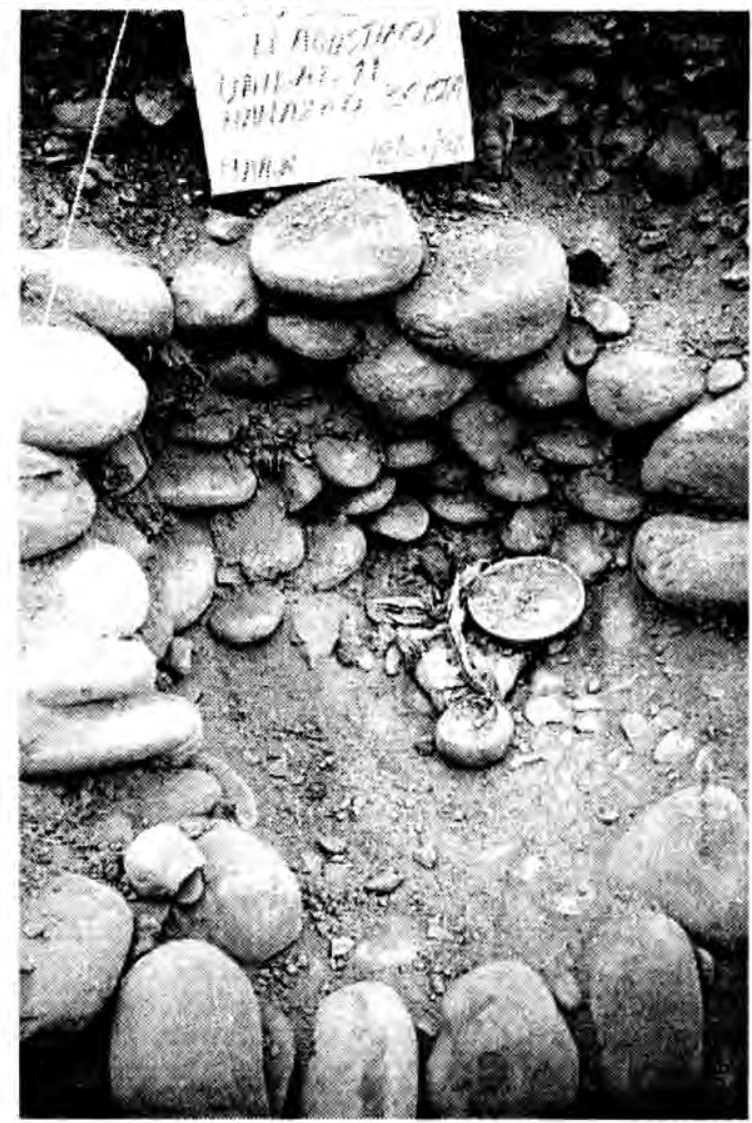

Fig. II Unidad 11. Hallazgo 3: Cista y Ofrendas

cuello; tiene sujeta una cuerda de algodón blanco atado a las asas y presenta huellas de hollín al exterior. En el interior se encontró tierra compacta adherida al fondo con huellas de descomposición. Hay una gran cantidad de larvas de insectos.

Dos de las ollas son muy semejantes entre si, variando ligeramente en las dimensiones principales y en algún detalle particular. Los cuerpos son globulares y la base cónica, el cuello es corto recto y divergente. Presentan dos asas pequeñas tubulares y horizontales sobre el hombro de la vasija. Están decoradas con pintura blanca alrededor del cuello y en las asas. Una contenía tierra, proveniente del exterior, en la que había corontas y panca de maíz, algodón en mata, fragmentos de soguillas, restos de roedores (Vasija 7). Esta vasija presenta una restauración en el tiempo de su uso. Al intentar cerrar una grieta se efectuaron perforaciones a lo largo de ésta para ser atravesadas con un hilo grueso de algodón. La siguiente olla contenía mazorcas de maíz. Cada olla estuvo cubierta con un mate.

La tercera olla es mucho más pequeña y diferenciada, de cuerpo globular y base cónica, cuello corto combado, presentando asas tubulares horizontales en el hombro de la vasija, decorada con pintura blanca difusa.

Se encontró otra vasija completamente fragmentada, con algunos faltantes importantes como el borde y la base del cuerpo; sin embargo, por el conocimiento del material, podemos indicar que corresponde a un cántaro de cuerpo globular y base cónica con asas planas perpendiculares en la mitad del cuerpo presentando engobe rojo oscuro. Al parecer, fue rota en otra parte y posteriormente colocada como ofrenda pero no completamente. Independientemente uno del otro, fueron colocados dos mates detrás de uno de los fardos; además se pudo recuperar un fragmento de gasa muy deteriorado.

Los fardos de los adultos se encontraban en posición erguida y mirando al Este. El fardo principal se colocó primero, directamente sobre el suelo. En este mismo nivel y tras de él, en un pequeño intersticio de la pared de guijarros, se colocó previamente la olla más pequeña. Frente a este fardo se pusieron las ollas con sus respectivos mates; a continuación se colocó el fardo marcado de rojo, casi encima del primero y apoyado en el lado norte de la cista. En esta misma posición y presionado por este segundo fardo, contra la misma pared, se colocaron dos mates en posición vertical. De la misma manera, en un espacio entre los dos fardos, se dispuso el cántaro más grande. Al lado derecho del fardo se pusieron los fragmentos del cántaro roto; sobre estos y apoyado contra la pared sur de la cista, se colocó uno de los fardcs de los niños en posición casi vertical. De igual manera el cántaro más pequeño, de cuerpo fitomorfo, fue puesto en un espacio entre este último fardo y el principal. Finalmente, se colocó el último fardo pequeño prácticamente sobre el fardo principal y apoyado sobre la pared de la cista. En todo momento se presentaron pequeñas cantidades de algodón sin cardar rellenando los espacios dejados entre cada elemento del entierro, con la finalidad de que sirvieran para amortiguar y para dar estabilidad a dichos elementos antes de sellar la cista.

\section{Contexto Funerario 11:}

El entierro es intrusivo en el Relleno 3 (Capa 6, ver fig. 6), para lo cual se excavó un agujero de aproximadamente 50 a 60 centímetros de diámetro, completamente irregular, colocándose el fardo en posición recta en el lado suroeste de la matriz; mirando en dirección contraria a ésta. Cerca a su base se depositó un cántaro.

$\mathrm{El}$ fardo visto de planta es casi rectangular; el cuerpo se encuentra envuelto en telas y finalmente se tejió una canastilla de totora que lo envolvía desde la base hasta la parte superior donde se dejó una abertura cuadrangular, que deja expuesta la tela. Sobre ésta se dibujó un símbolo en forma de $\mathbf{M}$ o $\mathrm{E}$ volteada. La base se encuentra bastante deteriorada, no por descomposición orgánica, sino por la depredación de roedores e insectos. En la parte más elevada y posterior, se sujetó un instrumento de madera a la soguilla del fardo con una cuerda más fina de algodón (ver fig.14).

El cántaro es de cuerpo lenticular y base cónica, de cuello compuesto y asas planas colocadas verticalmente en la mitad del cuerpo. Presenta decoración con pintura blanca alrededor del cuello y de las asas. El 


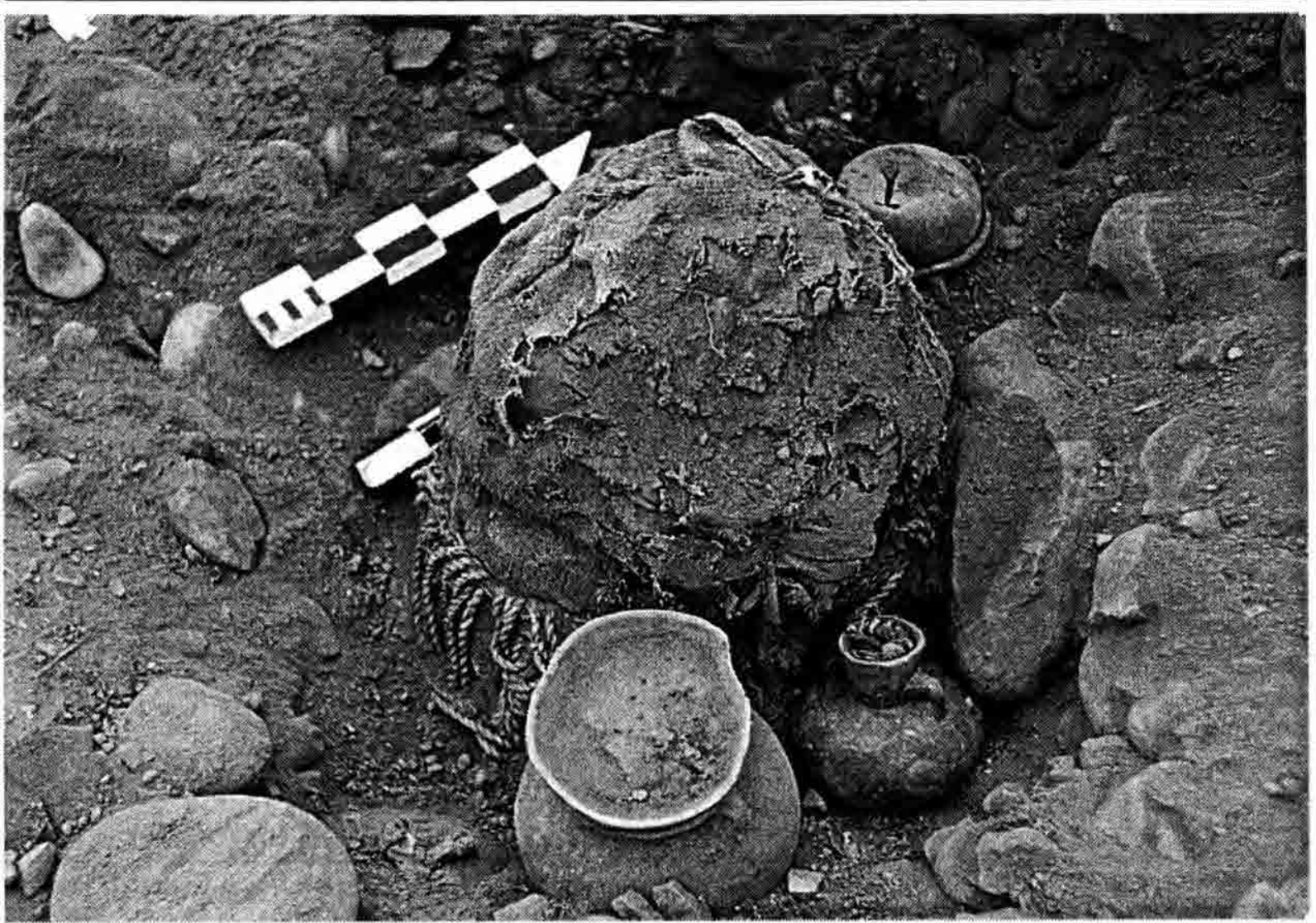

Fig. 12. Unidad 11. Contexto funerario 9

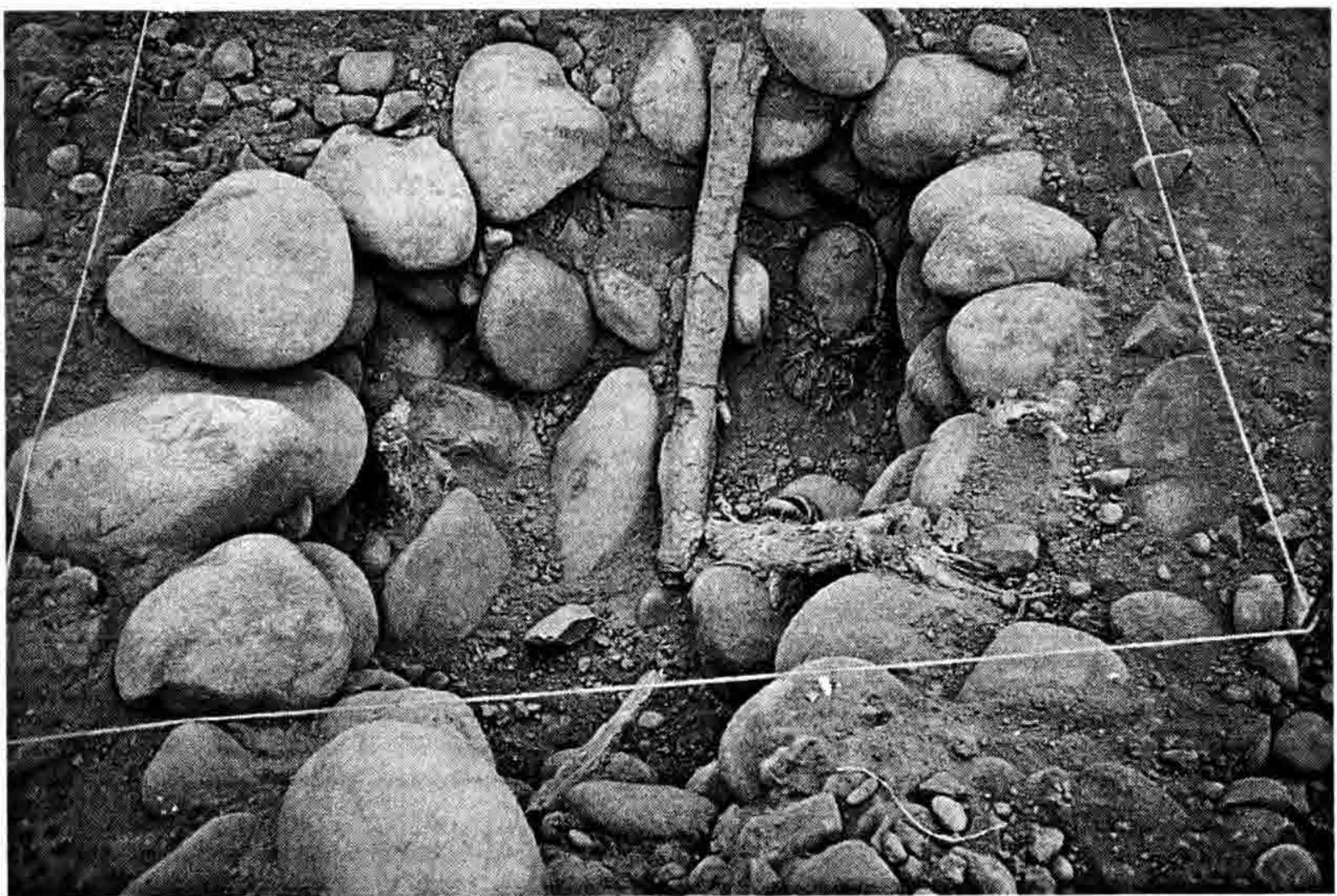

Fig. 13. Unidad 11. Contexto funerario 10 


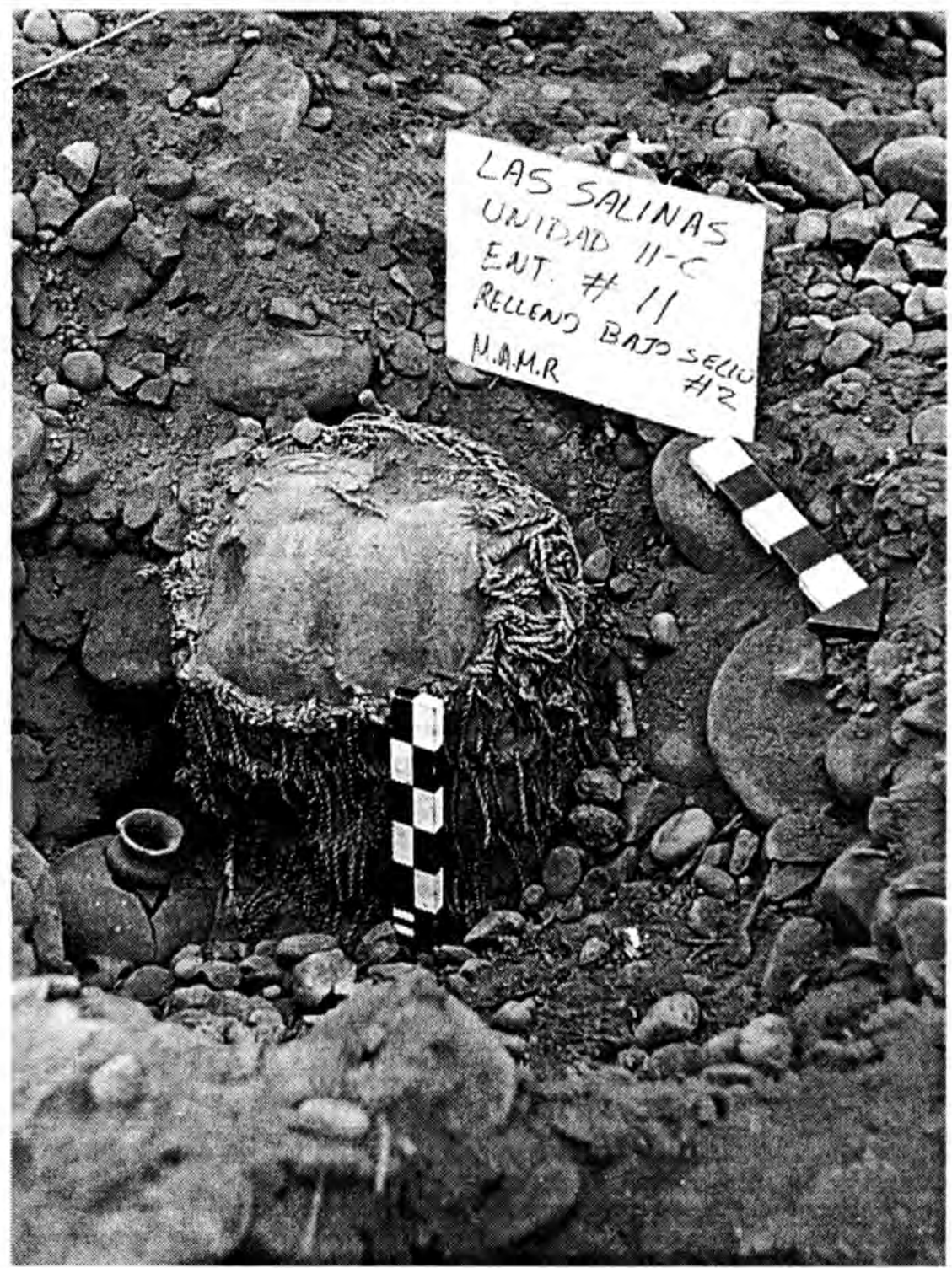

Fig. 14. Unidad 11. Contexto funerario II

borde está deteriorado, hay grietas en el cuerpo y le falta un asa. Este cántaro, al parecer, contenía líquidos; su boca estaba cubierta por un manojo de hojas de panca, estrujado y puesto a manera de tapón.

La matriz es más ancha en el borde que en su base. Primero se colocó el fardo y se aseguró su estabilidad con el mismo relleno; a continuación, se colocó el cántaro conteniendo algún líquido. Posteriormente, se cubrió completamente y al nivel de la superficie del relleno, se acomodaron guijarros de medianas dimensiones, de manera circular y cubriendo completamente el fardo, lo que al principio le dio la apariencia de la existencia de una cista.

\section{CONCLUSIONES}

Podemos asegurar, por las excavaciones en La Salina, que las estructuras de uso no doméstico formativas fueron utilizadas masivamente para fines funerarios durante los períodos tardíos, presentando un acondicionamiento de la estructura original, como lo demuestra la excavación en la Unidad 7 y 7 a.

En un segundo caso la estructura original fue cubierta completamente para ser usada como depósitos de ofrendas y entierros, como se aprecia en las Unidades 10 y 14 , de tal manera que se asemejaba a los verdaderos montículos funerarios.

En el tercer caso, al cual nos referimos detalladamente, los montículos fueron levantados exclusivamente con fines funerarios durante el Intermedio Tardío. Se caracterizan por tener casi 2 metros de altura, siendo sus diámetros de casi 8 a 10 metros, conformados íntegramente, en algunos casos, por acomodamientos de cantos rodados sin presencia de argamasa. En cada montículo se aprecia una secuencia de construcción, lo que tendía a aumentar el volumen del montículo, conservando sus formas circulares gracias a muros de contención levantados con los mismos cantos 
rodados y rellenados con tierra y basura para su ampliación longitudinal; mientras que la expansión en altura se efectuaba por sellos de arcilla y diversas capas de rellenos. Este proceso de construcción va acompañado de una serie de contextos funerarios que podrían indicar una secuencia cultural, como podemos apreciar detalladamente comparando las estructuras funerarias y el material cerámico de las Unidades 7 y 11 . En el caso de la Unidad 11, el hallazgo de un basural con material cerámico del Horizonte Tardío, asociado al último relleno de construcción y a cistas disturbadas, son contundentes. Adicionalmente, la Estructura Funeraria 2 (ver fig. 3,4 y 6) se encontraba cubriendo parcialmente el Contexto Funerario 4 que, a su vez, estaba asociado al Sello de Arcilla 1 (Capa 3), que definía una superficie horizontal en la cual se encontraban las bocas de las cistas de los contextos funerarios correspondientes al Intermedio Tardío.

Las fotografías aéreas de los años 40 nos permiten afirmar que montículos semejantes a los de La Salina se habían esparcido alrededor de los sitios arqueológicos más tempranos en esta parte del valle, como Granados, Sta. Felicia y Melgarejo; sin embargo, estos nunca fueron excavados y en la actualidad han desaparecido por el avance urbano, lo que confiere un carácter testimonial a los trabajos de La Salina y un alto valor arqueológico al área, ya que al final de nuestras excavaciones, quedaban aún muchos montículos intactos. Como apoyo a nuestras afirmaciones, podemos citar a R. Ravines (1985: 58), quien hace una referencia circunstancial al publicar una foto de las excavaciones en Granados, contextos que fueron detallados en el artículo de María Mendoza sobre las excavaciones de Sta. Felicia (Mendoza, 1983: 8-10). En esta publicación se describe un contexto funerario idéntico al de La Salina, pero intruyendo en la estructura arquitectónica de la pirámide Lima que, al parecer, también fue cubierta en parte o totalmente por rellenos de guijarros, costumbre que, al parecer, fue aplicada a las estructuras más tempranas.

Contextos posiblemente asociados a los excavados en La Salina podrían encontrarse en la necrópolis funeraria de Ancón, como lo expresa Kauffmann:

"La presencia de grandes montículos artificiales caracterizan y le dan personalidad a este sitio. La mayoría de estos montículos ya han sido removidos por investigadores como por huaqueros; sabemos que presentan gran cantidad de material orgánico, lo que ha traído grandes discusiones entre los investigadores relacionados con la problemática de los conchales. El problema se complica más cuando se registran contextos funerarios entre los estratos de basura; esta situación no ha sido aún bien estudiada. Nos referimos por ejemplo a la asociación de bocas de tumbas con un nivel de ocupación o etapa constructiva del montículo" (Kauffmann, 1994: 21).

Sin embargo, la evidencia deja de ser simplemente sugestiva al considerarse el gran porcentaje de contextos funerarios correspondientes a los períodos tardíos. Kaulicke también menciona la existencia de estos montículos en Ancón, sin dar mayores alcances (Kaulicke, 1997: 3-5).

Adicionalmente, podríamos otorgar un carácter regional a estos contextos; sin embargo, la ubicación cronológica del Intermedio Tardío para el valle del Rímac, aún no precisada, dificulta este análisis. La misma destrucción urbana dificulta asociar La Salina a un asentamiento cercano. Tampoco se descarta un uso funcional del área asociado al culto de los muertos. presente en la religión andina, en el cual se ligan la muerte y la fertilidad: hay que considerar que La Salina está a casi 100 metros de la bocatoma que da origen al canal de Surco.

\section{BIBLIOGRAFIA}

\section{KAUFFMANN, Federico.}

1994 "Proyecto Arqueológico Tumbas de Ancón (I)". En: Arqueológicas $N^{\circ} 23$. pp. 1-174. Publicación del Instituto de Investigaciones Antropológicas. INC. Lima.

\section{KAULICKE, Peter.}

1997 Contextos Funerarios de Ancón: esbozo de una síntesis analítica. PUCP, Fondo Editorial, Lima

\section{MENDOZA, María.}

1983 "Huaca Granados, Valle del Rímac". En: Gaceta Arqueológica Andina, Año 2, $\mathrm{N}^{\circ} 7$, pp. 9-10. Lima

\section{RAVINES, Rogger.}

1985 Inventario de Monumentos Arqueológicos del Perú, Lima Metropolitana (Primera aproximación). INC/Municipalidad de Lima Metropolitana. Lima

TABÍO, Emesto.

1965 Excavaciones en la Costa Central del Perú (1955-58). Academia de Ciencias, Departamento de Antropología, La Habana, Cuba. 


\title{
ENTRE EL MITO Y LA REALIDAD: LA IMPORTANCIA DE LA COYA EN LA SUCESIÓN DEL ESTADO INCA, DE HURIN Y DE VIRACOCHA
}

\author{
Ruth Shady Solís
}

\begin{abstract}
Sumilla:
Este articulo se inserta en una de las nuevas perspectivas con las que se da lectura a las crónicas, añadiendo a los referentes étnicos, politicos, económicos, religiosos, el componente género, el cual nos pernite entender el activo papel desempeñado por la mujer en la legitimidad, sucesión y reproducción del poder político en el Tahuantinsuyo. Haciendo uso de las fuentes escritas, la autora ensaya una interpretación de las alianzas y conflictos de los linajes pertenecientes a Hanan Cusco y Hurin Cusco; y la participación asumida por la coya, como representante de un linaje determinado. Asimismo, el artículo nos muestra cómo se fue configurando el escenario socio-politico, en el que años más tarde harían su aparición nuevos agentes sociales, los españoles. *
\end{abstract}

\begin{abstract}
This paper inserts in the new perspectives in chronicle analysis adding at the ethnic, political, economical and religious aspects of the document, the gender component. It show us the active role done for the women in the Tahuantinsuyo's legitimacy, sucesion and political power reproduction. Using the historical sources the author analyses the alliances and conflicts of the Hanan Cusco and Hurin Cusco lineage, and the Coya participation as a lineage representative. Also, the paper show us how the sociopolitical scene was delineated, until the appearance of new social agentes, the spaniards.
\end{abstract}

\section{INTRODUCCIÓN}

Los linajes y la división dual del Cusco en Hurin y Hanan han tenido estrecha relación con otros aspectos de la organización social, económica y política de la sociedad incaica y, al parecer, están arraigados en la misma formación de las sociedades andinas de la sierra, de la cual todavía conocemos poco.

En este ensayo presentaremos algunos temas relacionados con la organización social inca, en torno a la importancia de la casa religiosa de Viracocha y del Hurin Cusco. Suscitó nuestro interés las informaciones vertidas por algunos cronistas sobre la coya Mama Ocllo, esposa de Tupac Inca Yupanqui, personaje que, según la información contrastada, estuvo vinculado a Hurin y a Viracocha.

\section{Confrontamos las siguientes hipótesis:}

1. Los Hurin Cusco representaban al grupo que tenía control político en la zona del Cusco antes del cambio o revolución que hizo posible la hegemonía de Pachacutec y la instauración por él de los Hanan Cusco, cuyos linajes por dos generaciones en adelante detentarían el poder. La distinción entre Hurin y Hanan no fue nueva en los Andes, estaba arraigada en la tradición cultural, vinculada con los movimientos de poblaciones y la instalación de los recién llegados en territorios previamente ocupados. Hanan versus Hurin tendría su correlato en la oposición de Llacuaz y Huari en la sierra de Lima.

2. A pesar del nuevo status ganado por los Hanan, la nobleza de Hurin Cusco mantuvo, sin embargo, su poder y privilegios de clase como señores tradicionales. Al parecer, Pachacutec buscó legitimar el nuevo orden social, impuesto a través de acciones de conquista, por una alianza matrimonial que reforzara la nobleza de su linaje. Para ello, concertó el matrimonio de su hijo Tupac Inca Yupanqui con la noble de Hurin, Mama Ocllo. Posteriormente, Pachacutec eligió como su sucesor en el gobierno del estado al hijo de esta pareja, a pesar de su corta edad, pues él representaba al primer inca con derecho natural al gobierno después de Viracocha, su antecesor.

3. Según varios cronistas, la coya Mama Ocllo era considerada la mujer más rica y poderosa del imperio inca. Se la asocia a la nobleza de Hurin, vinculada a la casa religiosa de Viracocha. Si se considerasen algunos indicios sobre las normas de sucesión en las sociedades andinas, ella en su condición de mujer habría concentrado la riqueza de su linaje y se hallaba respaldada

Ruth Shady Solts. Arqueóloga, Profesora principal de la Facultad de Ciencias Sociales y Directora del Museo de Arqueología y Antropología de la Universidad Nacional Mayor de San Marcos.

* Miguel Angel Sulinas S. Antropólogo UNMSM. 
por el poder que éste tenía, como casa noble antigua, de gran prestancia y opulencia, relacionada con el Chinchaysuyo; sus hermanos eran gobernadores de esa importante provincia e incluso se decía que Mama Ocllo había nacido en Chincha. El matrimonio con esta coya habría significado para Tupac Yupanqui no sólo un refuerzo en el derecho de sucesión al gobierno por tratarse de una mujer principal y el acceso a los cuantiosos bienes del linaje de ella, sino el incremento de poder por la ligazón de los Yupanqui de Hanan con un linaje tradicional de Hurin y el apoyo de los nobles de este destacado linaje, gobernadores de una importante provincia.

4. La casa religiosa de Viracocha, tradicional y de gran prestigio en la zona del Cusco, antes de Pachacutec, poseía poder político y económico fuertes, y estaba ligada a la nobleza de Hurin. Como todo este grupo fue, asimismo, relegada frente a la nueva casa religiosa del Sol, que instauraron los Yupanqui de Hanan con Pachacutec. No obstante, al igual que las otras casas nobles de Hurin, mantuvo sus bienes y privilegios, atenta a las coyunturas políticas que le permitieran la recuperación de su anterior preeminencia.

5. De acuerdo con el sistema de clases de la sociedad inca, las casas nobles de Hurin, entre ellas la de Viracocha, mantuvieron sus privilegios de clase en el nuevo orden introducido por Pachacutec, porque representaban a la clase dominante de la sociedad a la que debió estar enlazado el grupo al que pertenecía el nuevo inca. Respetando sus privilegios, Pachacutec garantizaba igual tratamiento de parte de la clase popular a los de su propia clase.

6. Finalmente, en la contienda entre Guascar y Atahuallpa se enfrentaron los intereses de Hurin y Hanan, correspondientes a nacionalidades que no habían logrado borrar sus diferencias.

\section{LAOPOSICIÓN HANANY HURIN}

\section{a) En la referencia de géneros:}

En un mito registrado por Garcilaso se señala que el inca organizaba al Hanan y la coya colonizaba la parte baja o Hurin (Garcilaso, 1961: 43). Asimismo, Cobo refirió que llegados a Huanacaure, los hermanos Manco Capac y Mama Ocllo enviados por el sol dividiéronse por aquel valle, "el príncipe fue al septentrión y la princesa al mediodía... para convocar los moradores... con división de dos barrios, el uno de la gente que atrajo el príncipe, y el otro, de la que juntó la princesa... Los que atrajo el rey quiso que poblasen a Hanan Cozco;...y los que convocó la reina, que poblasen a Hurin Cozco ...para que quedase perpetua memoria de que los unos había convocado el rey, y a los otros la reina..." (Cobo, 1956: 148).
En la ceremonia por la muerte de Tupac Inca Yupanqui lloraban "hechos dos ejércitos, el uno todos varones y el otro todas mujeres" (Pachacuti, 1927: 202).

Se menciona también al grupo de linajes de las nacionalidades originarias del Cusco, identificado como Hurin frente al grupo de linajes de nacionalidades advenedizas (Acosta, 1987:425). Los primeros se identificaban con el dios Viracocha Pachayachachi.

Es interesante notar los términos usados entre los cusqueños: Yamqui significaba señor; conquistador, Hanan; Lari, hermano de la madre y conquistado, Hurin.

\section{b) En la referencia a territorialidad:}

La diferenciación en Hanan y Hurin se puede correlacionar con la tradicional oposición existente en las sociedades andinas de la sierra central y meridional, entre los habitantes de las tierras altas, puna, pastores y cultivadores de tubérculos; y los de valle, agricultores. Los unos conquistadores, foráneos y advenedizos; los otros originarios, naturales, conquistados. Oposición que en Cajatambo, sierra de Lima, apareció mencionada como Llacuaz versus Huari o en Ocros, Llachuases frente a Llactas. "Los Llacuaces fingieron ser hijos del rayo, trueno y a estos fue su adoración, y al sol. Los Llajtas fingieron proceder de las huacas y que su origen es dellas" (Hernández Príncipe, 1621:51). Creemos que esta distinción expresaba la antigua lucha o confrontación entre los pobladores de las punas y los que habitaban los valles. Los primeros ambicionaban los territorios de los agricultores, los conquistaban y/o se casaban con sus hijas para legitimar su posesión, convirtiéndose con el tiempo en Huaris o Hurin. Quedaban en ese estado expuestos a la conquista por otros grupos bárbaros, y así sucesivamente. Oposición que representaba a nacionalidades diferentes que, en el caso del Cusco, no tuvieron tiempo de borrar sus distinciones.

Silverblatt (1978:333), en base a Ramos Gavilán (citado por Porras), mencionó que los de Hurinsaya consideraban a los de Hanansaya como pobres advenedizos, sin tierra ni patria propia. Betanzos se refirio a Hanan y Hurin como naciones: "Huascar era hijo de la noble Ragua Ocllo de la nación de Hurin Cuzco" (Betanzos, 1987:194).

En la sociedad inca, líderes como Manco Capac y, posteriormente, Pachacutec aparecen asociados a dioses y territorios de altura. Ellos se habrían asentado en el valle del Cusco por conquista y matrimonio con las hijas de jefes étnicos locales. Eran hombres Hanan que se vincularon a mujeres Hurin.

La marcada distinción de género o procedencia ha quedado expresada en una serie de costumbres y ritos, donde aparece la mujer asociada a la tierra y a la 
agricultura. Hernández Príncipe cita: "es tradición antigua, porque ni el inga hizo mucha cuenta de la adoración de la luna por ser a cargo de las mujeres, como de Mama Huaco, hermana de Mango Capac, por haber sembrado el primer maiz que hubo..." (ibid:53). Imaginaban a la luna en forma de mujer "... estaba a cargo de mujeres que hacían oficio de sacerdotizas; $y$ cuando se sacaba fuera, la llevaban ellas mismas en hombros" (Cobo, 1956: 364), Dice Zuidema que "eran vistos los grupos de hombres y mujeres como dos sociedades diferentes..." y plantea la hipótesis de la "transmisión paralela cruzada": "los libros de bautizo indican que los hombres recibían apellido del padre y las mujeres de la madre desde fines del siglo XVI hasta el XVII" (Zuidema, 1980: 53).

En la fiesta estatal de Coya Raymi, en setiembre, realizada para indicar el comienzo de las lluvias y del ciclo agrícola, sacaban en el Cusco, según Molina, a una figura de mujer como a la huaca de la luna, a cargo de mujeres. Igualmente, Mama Huaco era venerada por sus conocimientos de la agricultura y las mujeres se encargaban de su culto (Silverblatt, 1978:299-336).

En la ceremonia de Capac Raymi participaban activamente mujeres y doncellas nobles de 12 a 14 años; el sacerdote principal del sol, haciendo reverencia primero a Viracocha y luego a las demás estatuas, ofrecía las alpacas de parte del sol a Viracocha. Las doncellas recibían, del sacerdote del sol, vestidos, y cumplían la función de darles chicha en las pruebas que los nobles realizaban. "Las parcialidades de Hanancuzco y Hurincuzco estaban cada una aparte" (Cobo, op. cit: 115-125). En la fiesta de Camay, igualmente, poníanse junto a la estatua del sol y le ofrecían alpacas a Viracocha en nombre del sol: "Estos carneros te ofrece el sol, por su conservación y fuerza y porque siempre alumbre..." (loc.cit). En la fiesta de Inti Raymi las estatuas del sol enviaban alpacas al cerro Manturcalla con las insignias reales, Sunturpaucar, y las ofrecían a Viracocha (ibid: 126, 134).

Conı ya se señaló, en la ceremonia por la muerte de Tupa Inca Yupanqui se formaron dos grupos: uno de hombres y otro de mujeres para llorar por separado.

Es interesante indicar que Hanan y Hurin estaban relacionados, asimismo, con diferentes sistemas de irrigación: Hananchacan y Hurinchacan (Mitchel, 1981: 158); lo cual no es de extrañar si se considera que cada uno habría sido implementado por grupos distintos, dentro de un programa de habilitación de tierras.

En la sociedad inca, esta división habría estado presente en la organización estatal, en las acciones del gobierno y en la sucesión imperial. El rol de la madre era clave para la ubicación social del individuo y su acceso a los cargos políticos. Como veremos, la guerra entre Atahualpa y Huascar no habría sido sino el enfrentamiento entre los Hanan (Atahualpa) y los Hurin (Huascar), filiación que les sería transmitida por sus respectivas madres.

\section{PACHACUTEC,LAINAUGURACIÓNDEUNACASA REAL Y EL NUEVOORDENSOCIOPOLÍTICO}

Inca Yupanqui o Pachacutec parecería haber sido un personaje de nacionalidad allegada a los habitantes del Cusco, quizás integrante de una confederación regional, que se rebeló y afirmó la usurpación de poder a través de acciones militares.

La victoria de Pachacutec permitió: 1. El acceso al gobierno de un linaje nuevo, de Hanan, en oposición a los de Hurin, que tradicionalmente lo detentaban; y 2 . El reemplazo de la casa religiosa de Viracocha por otra representada en el nuevo culto al sol. Llamaron a Pachacutec, Indichuri, hijo del sol, y al ser ungido por el inca depuesto, Viracocha, éste le dijo: "Verdaderamente tú eres hijo del sol e yo te nombro rey y señor y tomando la borla... e la puso a Inga Yupangue... y lo nombró Pachacuti Inga Yupangue Capac e Indichuri vuelta del tiempo" (Betanzos, op.cit.: 83). Nombramiento que aludía al cambio revolucionario o a la transformación del sistema. No obstante, el derecho señorial de Viracocha no fue eliminado y se le permitió mantener sus dominios en Caqui Jaguana. Es interesante notar que, después de usurpar el gobierno, Pachacutec no sólo no se hizo nombrar inca sino que esperó afianzar su poder militar en la región para exigir luego, del antiguo monarca, su proclamación.

Si bien el cambio significó el ascenso al poder de un nuevo linaje y su enriquecimiento a través de las conquistas efectuadas por el gobierno, este grupo buscó afianzar sus derechos reales mediante alianzas matrimoniales.

El nuevo orden social establecido favorecía al linaje de los Yupanqui, "Iñaca Panaca o Hatun Ayllo" de Hanan Cusco, y a los linajes de tres casas nobles tradicionales de Hurin Cusco: Vicaquirao Panaca, ApoMayta Panaca y Quilis Cache (¿Ahucani Ayllu?). Estos tres linajes, según se refiere, habrían apoyado a Pachacutec en la lucha contra los Chancas y en la rebelión contra el antecesor, acciones que le permitieron a él afirmar la usurpación del poder. La nobleza restante de Hurin, aunque perdidas sus preeminencias, continuó manteniendo sus posesiones y prerrogativas de clase.

Así, al mantener el respeto por la jerarquía social, Pachacutec, identificado con la clase dominante, defendía el status superior de ésta contra la insubordinación de la masa. El respeto por el orden social de clases, ya establecido, garantizaba la continuidad de la dominación, 
Pachayachachic, que ubicó en Quishuarcancha a la derecha de la imagen del sol y otra del trueno y rayo, Chuquiilla, que ubicó a la izquierda. Chuquiilla se le había aparecido como serpiente de doble cabeza, era su huaca personal: "... El trueno, a quien en autoridad y honra daban el segundo lugar después del sol..." (loc. cit). "Tenía el trueno templo propio en Totocancha en el cual estaba una estatua de oro en andas que hizo el Inca Pachacutec en honor al trueno y la llamó Intillapa a la cual tomó por hermano y mientras vivió la trajo consigo en la guerra... era dios general, tenía en todas partes imágenes y guacas y adoratorios, sus sacerdotes iban a la puna o páramo a ofrecerle sacrificios" (ibid: 368-370). Es más, "sepultaron a este inca en Patallacta de donde lo mudaron a Totocache" (loc.cit.). Estos pasajes sugieren que Pachacutec procedía de tierras altas, pues tenía como dios propio al trueno; al imponerse sobre los habitantes del valle adoptaría a los dioses solares de los agricultores, al sol, a otras versiones de soles y a uno antiguo, muy prestigioso en el área, Viracocha.

Observamos la interrelación y coexistencia entre distintas creencias, y una que expresaría bien la tradicional oposición de la sierra andina: entre dioses vinculados a la tierra y a los agricultores, Viracocha, el sol; y aquellos relacionados con las tierras altas, el ganado y los pastores, el trueno o rayo. En la siguiente cita, destaca la filiación del Cusco con el sol, al hacer sus sacrificios... decían así: "oh sol, padre mío, que dijiste: haya Cusco, y por tu voluntad fue fundado y se conserva con tanta grandeza" (Ibid.: 205).

En las sociedades andinas los dioses representaban a grupos étnicos; su posición, importancia o pérdida de rango revelaban la historia y vicisitudes de sus pueblos, de sus victorias o derrotas. La persistencia de cultos paralelos representaría la convivencia de naciones bajo un determinado régimen político hegemónico.

Huascar, identificado con Hurin, no sólo rechazó su filiación con Hanan sino que se enfrentó a la iglesia que este grupo había privilegiado, y despojó al templo del sol. Mandó que le quitasen las tierras de coca y maíz.

La filiación de los dos últimos incas con los dioses de sus respectivas agrupaciones es reveladora. Al ser apresado Huascar por los generales de Atahualpa, sus capitanes, por orden de aquél, acordaron hacer un gran sacrificio al Viracocha Pachayachachic (Acosta, op.cit.: 425). Atahualpa, en cambio, ya vencedor de Huascar, se enojó con el sacerdote de la Huaca Catequil porque le mencionó a Viracocha "como dios que lo era de Huascar y su linaje más no de él". Lo mató e hizo quemar el cerro donde esta huaca se hallaba, hasta destruirla (Betanzos, op.cit.: 249-254). Triunfante
Atahualpa, los señores cusqueños dieron gracias al sol en nombre del inca (ibid: 259 ).

Vemos pues que la relación competitiva entre Hanan y Hurin era, asimismo, la que tenían las casas religiosas del Sol y de Viracocha; con la primera se identificó el linaje de los advenedizos, con la segunda estaban los grupos más tradicionales, a los que aquél sojuzgó. Ambas casas religiosas ya tendrían culto y prestigio entre las sociedades agrícolas del área antes de que tomase el gobierno Pachacutec.

\section{LA IMPORTANCIADE LAMUJER EN LOSANDES}

A diferencia de otras sociedades, la mujer en los Andes ocupó una posición relevante. Ella estaba ligada a la fecundidad de la tierra, a la posesión de ésta y, a través de ella, se identificaba cada linaje y dominio señorial.

La iconografía religiosa andina muestra relevantes representaciones femeninas en diversas sociedades a lo largo del territorio y en diferentes etapas, desde el Formativo, siempre en una posición expectante. Se ha llamado la atención sobre la figura de la vagina dentada, identificada en imágenes de gran relieve como el Obelisco Tello de Chavín de Huántar, la estela de Pacopampa, la litoescultura Yaya Mama del altiplano del Collao, las telas pintadas de Carhua, Paracas, la deidad de Pachacamac, de las urnas de Pacheco, etc. (Lyon, 1978: 95-144), todas son imágenes femeninas posiblemente asociadas con la tierra, la agricultura y la irrigación. Personajes femeninos, igualmente relevantes, son mencionados en los mitos descritos por los cronistas, en roles relacionados mayormente con la actividad agraria; tal es el caso de Mama Guaco y el cultivo de maíz en la fundación del Cusco, resaltada como hermana más que esposa de Manco Capac (Sarmiento de Gamboa, op. cit.: 58); Manañamca y Chaupiñamca, diosas de la Chaupi yunga, es decir de tierras propicias para el cultivo de coca en el valle del Rímac; Urpay Huachac, esposa de Pachacamac, criadora de peces en estanques de agua; Choquesuso, inspiradora para la construcción de un canal de irrigación en el ayllo Copara de Yauyos; la madre Rayguana de Caina, Caj.tambo, poseedora de los cultivos que se distribuyeron a serranos y yungas, etc. Un personaje como Mama Guaco es descrito con similares atributos de jerarquía que Manco Capac, en cuanto a la toma de decisiones, según se aprecia en el mito de los hermanos Ayar y la posesión de las tierras del Cusco.

En la sociedad inca el mes de setiembre estaba consagrado a la reina, era el primer mes de las siembras "en el que las mujeres tenían derecho de invitar a los hombres..."(Zuidema, 1991:125).

La división de géneros se vuelve a observar entre la gente de Mama, en Lima, cuando cuentan que 
la huaca Maclla, esposa del dios Wallallo, animaba a las mujeres, en tanto él animaba a los hombres (Taylor, 1987:223).

En el altiplano del Collao, la mujer le decía al hombre: "has criado bien a tu hija" y el hombre le decía a la mujer: "has criado bien a tu hijo" (Bertonio, 1965: 293).

En la sucesión del gobierno, la posición social de la madre determinaba, al parecer, los derechos del hijo a la herencia del señorío. Muerto el señor o curaca le sucedía el hijo de más valer; entendemos, aquel habido en la mujer de más alta jerarquía entre todas.

Durante el imperio incaico, sucedía al inca el hijo de la Coya o mujer principal, entre los muchos hijos que éste podría haber tenido en varias mujeres. Este hijo heredaba el estado, mas no representaba al linaje del inca fallecido ni poseía los bienes de éste. En la fundación del Cusco, los 4 hermanos Ayar y sus 4 esposas quedaron reducidos a Manco Capac y las 4 mujeres por la sucesiva desaparición de los varones. No obstante ésto, los linajes quedarían representados por las mujeres.

Observamos que la identificación de un individuo se hacía a través de la hermana del padre, la ipa o pana (el hermano de la madre es lari). El término panaca refería a los descendientes de la hermana (Sarmiento de Gamboa, loc. cit.: 58). La panaca daba la ubicación social de ego y su acceso a los bienes administrados por ésta. Un buen ejemplo en la sociedad inca lo constituye el caso de Yahuar Huaca, hijo de Inca Roca con Mama Micay, hija del cacique de Guayllacan. El hermano de ésta pidió le enviasen al hijo habido en Mama Micay "porque, mientras era nin̄o, le querría regalar y dalle a conoscer sus deudos de parte de su madre y sus heredades y le querrían hacer su heredero en vida de sus haciendas" (Ibid.: 72). Similar alusión a la filiación por medio de la mujer se infiere del relato sobre el castigo que hizo Pariacaca a la comunidad de los Huayquihusa en Huarochiri por no haberlo invitado a participar en su fiesta; exceptuó de dicha sanción a una mujer: "ésta, sus hijos y sus hermanos se salvaron" (Taylor, op.cit.:125).

El rol de las mujeres en la identificación de los linajes ha quedado expresado en su participación en la ceremonia para el reconocimiento social de los orejones o nobles incas: "Se juntaban las mujeres de la familia de tales deudos, los padres tráan lana negra que repartían entre dichas mujeres para que las hilasen e hiciesen camiseta. Los mozos recogen haces de paja y los entregan a las mujeres..."(Betanzos, op. cit.: 66-67).

Una de las ordenanzas dictadas por Pachacutec disponía que a la muerte del primer marido, "la tal mujer se volviese a casar con el pariente más cercano del primer marido, porque si hijos les quedasen de tal marido, primero los criase como propios y si no dejase hijos del primer marido, el segundo del mismo linaje los hiciese y el linaje fuese adelante" (Ibid.: 110). No tenemos todavía suficiente información, pero suponemos la importancia del rol de la hermana del padre para la ubicación social.

La alegría demostrada por Pachacutec ante el matrimonio de su hijo Tupac Inca Yupanqui con Mama Ocllo fue no sólo porque ella pertenecía a la nobleza tradicional, sino porque representaba a un importante linaje, vinculado con la casa religiosa de Viracocha, además de su riqueza.

La celebración que hizo Huayna Capac cuando le informaron del nacimiento de la hija de su primo hermano de padre, Yarnqui Yupanqui, debió estar en relación con la importancia del linaje de los Yupanqui, que ella representaba, y con la herencia de los bienes de este linaje. "Huayna Capac se alegró y dispuso se hiciera gran fiesta, y cuando cumplió ella un año, dijo que sería piviguarmi de su hijo" (loc. cit.). Ella, Cuxirimay Ocllo o Angelina Yupanqui, aún siendo niña, habría sido casada con Atahuallpa, primero y, posteriormente, con Francisco Pizarro y con el mismo Betanzos. Según este cronista, Atahuallpa recibió la borla real de su primo hermano Yamqui Yupanqui y se casó con Cuxirimay, hermana de éste y heredera de los bienes de la panaca Yupanqui, de Hanan.

Cuando Atahualpa ordenó el apresamiento de Huascar señaló que se lo enviasen junto con su madre y su mujer principal Chuquihuipa "porque pienso hablar con el Huascar y con su madre y saber dellos por qué se me envió al Quito" (Ibid.: 251).

Como parte de la política imperial de dominación de las provincias, Pachacutec daba a los caciques y señores de los pueblos conquistados "unas señoras naturales del Cusco y de su linaje para que fuesen cada una destas mujer principal del cacique... e que los hijos en las tales hubiesen fuesen herederos de los tales estados e señoríos que sus padres tuviesen fundándose" (Ibid.: 57). Con este procedimiento, el rol de la mujer era asegurar para el incario el dominio o gobierno a través de la familia que ella fundaba. De otro lado, el inca mismo se casaba con mujeres de los señores étnicos conquistados, ellas eran sus esposas secundarias.

El documento de Huarochirí informa que el inca Huayna Capac dispuso que todas las provincias dominadas le enviaran una "hermana" para desposarla. Con este comportamiento de significado sociopolítico, el inca se posesionaba, por derecho, de los bienes de los señores étnicos regionales. Un caso ha sido descrito en relación con Huayna Capac, quien tomó como mujeres secundarias a Contarguacho y Añas Colque; la primera era hija de Pomapacha, cacique principal de la provincia de Hatun Anan Huaylla; y la segunda era hija de Huacachillac, lider étnico de Hurin 
Huaylla. A cada una el inca les habría señalado seis guarangas en sus propias tierras de Guaylas (Espinoza 1978: 247-298). Como declar6 el testigo cacique Finchica de Huaraz "el padre de Contarguacho era cacique principal de la dicha provincia, e que por tal hija de tal cacique el dicho Guayna Cava la tomo por mujer" (Ibid.: 286).

Dentro de este comportamiento se enmarca la afirmación del cronista Sarmiento de Gamboa quien dice que, por ley, todas las mujeres del imperio inca pertenecían por pleno derecho al soberano como esposas, y que él las redistribuía a sus futuros esposos. Se reproduce el modelo del inca conquistador de territorios y poseedor, por tanto, de las mujeres que representaban a éstos. Esa significación debió tener la institución de las acllas: garantizar la posesión de territorios ganados por el imperio.

Quizás otra expresión de la asociación mujer y posesión de la tierra se vea reflejada en el comportamiento de los "parianas", individuos elegidos cada año para la guarda de las chacras. "Andan con unos pellejos de zorra en la cabeza, y bordones con unas borlas de lana en la mano,... y mudan al hablar la voz, hablando mugeril y afetadamente" (Arriaga, 1920: 36). Pasaje que también es descrito para Cajatambo (Duviols, 1986: 446) y que se representa, en la actualidad, en la tradicional fiesta del Colliriti.

Como en toda sociedad de clases, hay menciones al status elevado de la mujer: "esta coya, raras vezes tenía conversación con gente común ni indias ordinarias" (Murúa, 1987: 62).

Es interesante notar que, a la muerte del inca Viracocha, fueron sólo mujeres las que salieron en procesión en el Cusco, "haciendo llantos y lloros, tresquilados y con fajas negras, y el rostro, todo hechas negras, con Winchas de tunissa o quisva... y desnudas hasta medio cuerpo, azotándose... y otras yndias con tamborcillos pequeñuelos, y echándose con cinezas en las cabezas ... Y dicen que estas pallacunas y viudas y viejas, toda aquella semana anduvieron buscando por todos lugares a do había andado dicho difunto. $\mathrm{Y}$ por Pachacutyngayupanqui hacenle burlas;... y a la mañanita les pregunta: ah vieja mi madre ¿tanto amor tenéis de vuestro marido mi padre? Muy bien habéis llorado; y quando muriedes quién os llorará desta manera" (Pachacuti, op.cit.: 185-186). Aparentemente, estas demostraciones se hicieron en señal de protesta por la forma en que Pachacutec realizaba las exequias del inca fallecido, revelan, sin embargo, la importancia social de la mujer y su clevado status como miembro de la clase alta. La censura de las mujeres encubría, en la ceremonia por el muerto, su disconformidad con el ascenso al gobierno de un linaje ajeno.

\section{LA IMPORTANCIADE LA COYA MAMA OCLLO}

Como en toda sociedad de clases, la inca protegió con normas explícitas la sucesión del gobierno. De los varios hijos que tenía el inca o un señor principal, heredaba el imperio o señorío aquel hijo habido en la coya o señora igualmente principal. Al margen de la edad, consideraban que este hijo era el de más valer.

Recogiendo la tradición cultural andina, Pachacutec señaló que heredaba el cargo o estado el hijo "habido en la mujer principal de su deudo e linaje hermana suya o prima hermana suya a la cual llamaban Piviguarmi y por otro nombre Mamanguarme... había de ser de padre e de madre derechamente señora e deuda del inga sin que en ella hubiese raza ni punta de Guacha Concha... sus hijos se nombraban Pivichuri (hijo del hombre), hijos del inga en esa piviguarmi" (Betanzos, op.cit.: 78)

Según Betanzos, Pachacutec tuvo muchos hijos, algunos muy queridos como Yamqui Yupanqui (posiblemente el hijo de su hermana), quien estuvo a su lado y cogobernó con él cuando ya estaba avanzado en edad. Este hijo heredó el señorío dominial o panaca del inca, Panaca Iñaca o Hatun Ayllo. Pero la sucesión del gobierno recayó en Tupac Inca Yupanqui. Creemos que privilegió esta sucesión el matrimonio de Tupac Inca Yupanqui cun Mama Ocllo "la cual era muy querida de su padre..." (Ibid: 127-129); no pensamos, como Zuidema (Ibid.: 67), que fuese la actitud pacífica que el otro hermano tenía.

Mama Ocllo fue señalada como "la mujer más venerada que hubo entre estos indios" y tenía adoratorios en los ceques del Cusco, vinculados principalmente con los del Chinchaysuyu: $\mathrm{Ch}-3: 3, \mathrm{Ch}$ 9:2 y una chacra en el Collasuyo: $\mathrm{Co}-3: 5$, la tercera huaca del tercer ceque Collana del Chinchaysuyo "era otra fuente llamada Ticicocha... Fue esta fuente de la coya o reina Mama Ocllo, en la cual se hacían muy grandes y ordinarios sacrificios, especialmente cuando querían pedir algo a la dicha Mama Ocllo"(Op. cit. t.IV:18).

Parece que esta coya pertenecía al grupo de Hurin Cusco, un hermano suyo, Achache, era gobernador del Chinchaysuyo. "Dicen de ella haber sido muy hermosa y discreta y mujer de gran consejo y prudencia". Mama Ocllo habría estado vinculada, asimismo, a la religión y, no sería raro, a la casa de Viracocha. Informó Murúa que: "hizo su marido por amor della un temiplo famosísimo en la fortaleza de la ciudad del Cusco... y una entrada... que era una boca de serpiente...". En este templo de la fortaleza, que se comunicaba con el Coricancha, según este cronista, residió mucho tiempo la coya. "Asistían con ella más de cinco mil indios e indias de sus criados, que las servían y todos dormían dentro y comían a su costa, 
porque era riquísima. Tenía muchos pueblos para su fábrica y reparo deste templo" (Murúa, op.cit.: XXVII: 100).

Guaman Poma señalaba que esta señora "ciempre tenía por camarera y donzella a yndias biejas de ochenta años y por lacayo tenía biejos y en toda su casa que llaman mamaconas y pachacas" (op. cit.: 139).

En base a la información mencionada, sugerimos que la coya Mama Ocllo, cusqueña nacida en Chincha, estaba asociada con el linaje de Hurin, con Viracocha y con el Chinchaysuyo. El matrimonio de Tupac Inca Yupanqui con ella unió a la casa Yupanqui de Hanan con una muy importante de Hurin, y significó para sus herederos mayores derechos a la sucesión, aparte de apoyo político y riqueza de la antigua nobleza. Asimismo, se reiniciaría el retorno de los Hurin al poder del estado, al derecho de sucesión del gobierno, pero también de las tensiones, que se agudizarían a la muerte del heredero de esta conjunción, Huayna Capac.

La importancia de esta coya, por otro lado, revela el poder que continuaba teniendo el grupo Hurin como nobleza tradicional. Tupac Inca Yupanqui encargó que "tuviesen cuidado de mirar por su mujer Mama Ocllo... y que la respetasen todos como a su señora y madre y que hiciesen lo que ella les dijese y rogase paresciéndole que era cosa que conviniese al bien del Cusco..." (Betanzos, op. cit.: 176).

Cuentan que a la muerte de Mama Ocllo, su hijo Huayna Capac no salió de su aposento un mes, llorando la desaparición de su madre, y le hizo la ceremonia Purucaya de entierro con el boato que solían mostrar por los monarcas incas. "El duelo fue grande y le hicieron bulto... y pusiéronlo en su casa y pintaron una luna en el lugar do estaba" (Ibid.: 190). Asimismo, este inca hizo construir en Ecuador el templo de Lullocancha en honor de su madre y colocó allí la estatua de Mama Ocllo.

\section{HUAYNA CAPAC Y LA CONJUNCIÓN DE HURIN Y HANAN}

Pachacutec, quien llegara a asumir el gobierno por usurpación, se preocupó en nombrar como su sucesor a Huayna Capac, hijo de Tupac Inca Yupanqui y Mama Ocllo, descendiente del matrimonio que habría legitimado la estirpe real de los Yupanqui.

El nacimiento de Huayna Capac habría sido muy celebrado por Pachacutec, quien manifestó: "este será en lugar de mi persona" y lo nombró su sucesor: "en presencia de todos los señores del Cuzco tomó una borla y atadura de cabeza... y púsosela al niño en su cabeza... que entonces tenía seis meses..." (Ibid: 131).
Huayna Capac llevó el apelativo de Capac (señor, rey), calificativo que no estuvo asociado a Pachacutec ni a su cogobernante, su hijo Yamque Yupanqui o al hijo que lo reemplaz6, Tupac Inca Yupanqui.

Acosta señaló que "Huayna Capac fue adorado por los suyos, como dios, en vida, cosa que afirman los viejos que con ninguno de sus antecesores se hizo". Fue visto como el de más valer. Esto posiblemente por ser el máximo exponente de los Hanan y Hurin. Su ascenso al estado inca, sin embargo, no fue fácil, estuvo acompañado de varias revueltas.

Anteriormente, cuando muere Pachacutec, asumió el control del estado su hijo Tupac Inca Yupanqui, con la colaboración de su hermano Yamqui Yupanqui. Gobernaron, aparentemente, sin conflicto porque el grupo de Hurin ya estaba representado a través de la coya Mama Ocllo y sobre todo por Huayna Capac el heredero. Yamque, de la panaca Iñaca, cuidaría de los intereses de Hanan. El poder quedó distribuido del siguiente modo: el hijo de Yamque fue encargado de administrar el ganado del Cusco y el otro, Huayna Capac, el ganado del sol (lbid.: 175-176).

No obstante, a la muerte de Tupac Inca Yupanqui hubo problemas, pues un hermano de padre de Huayna Capac, Capac Huare, y un tío paterno suyo, Hualpaya, intentaron usurpar el poder. Pero los derechos de Huayna Capac fueron defendidos por sus tíos maternos, hermanos de Mama Ocllo, del linaje de Hurin y, en particular, por Achache, el hermano gobernador del Chinchaysuyo, quien descubrio el complot de Hualpaya.

El distanciamiento entre Hurin y Hanan se hizo más evidente durante el gobierno de Huayna Capac; ya no fue notoria la participación de Yamque, su primo hermano, como ocurrió con su tío en el gobierno de su padre.

Es interesante notar que en el gobierno de Huayna Capac hubo fuerte injerencia de los Hurin, e incluso se edificó un templo a Viracocha y se le dio bienes, al igual que hiciera Pachacutec con la casa del sol. Con ese inca se inició el retorno al poder estatal de los Hurin y fue mayor la competencia entre las casas reales y religiosas. Pero él, como descendiente directo de ambos grupos y por el reconocimiento que recibía de los dos, pudo mantener cierto equilibrio.

Ya hemos mencionado que en la organización de la guerra contra Quito, Huayna Capac envió a sus ejércitos del Collao, Contisuyo y Antisuyo con capitanes inca, pero él personalmente fue con la gente del Chinchaysuyo, provincia gobernada por los hermanos de su madre, "a quienes había mandado llamar 
secretamente y a quienes consideraba la gente de más lustre de todo su ejército" (Murúa, op. cit.: 111). El antagonismo entre los Hanan y Hurin se expresó en el conflicto que se suscitó en la conquista de los Cayambe. entre Huayna Capac y los orejones cuzqueños, con el amotinamiento de éstos y su amenaza de retorno al Cusco. El inca para calmarlos sacó el bulto de su madre Mama Ocllo(Ibid.: 124).

\section{LOS PROBLEMASDE LASUCESIÓN DE HUAYNA CAPAC}

Siendo Huayna Capac el primer inca que representaba la unión de los linajes de Hurin y Hanan y el retorno de Hurin al poder, después de la usurpación de Pachacutec, desde muy temprano, y aún cuando el inca estaba joven y sano, ya los de Hanan le expresaron su preocupación porque se designara al heredero, mostrando así sus inquietudes por la sucesión.

Huayna Capac habría designado como heredero a un hijo suyo, aún niño, Ninan Cuyochi, quien murió casi junto con él en la epidemia de viruelas. Sus hijos Huascar y Atahuallpa pertenecían por sus madres a dos linajes opuestos, y en la lucha que se trabó entre ellos se reflejó el desenlace de las tensiones suscitadas en los Hanan desde el retorno de los Hurin al poder, con Huayna Capac.

Huascar había nacido junto a la laguna de Mohina, era hijo de Huayna Capac con la noble Ragua Ocllo o Pilco Huaco de Hurin Cusco (Op. cit.: 194). Se casó con Mama Huarcay o Chuquillanto o Chuquihuipa, al parecer perteneciente a un linaje de Hanan. Este matrimonio tuvo la oposición de su madre, por lo que acudió a solicitar autorización al cuerpo de Tupac Inca Yupanqui y al sol. En su boda se engalardonaron las casas de Tupa Inca Yupanqui y la de Huayna Capac e hizo traer al sol y al inca fallecido, y él y Huayna Capac celebraron la fiesta para aquellos que le daban la esposa. Tiempo después, Chuquihuipa se quejó con los emisarios de Atahuallpa de los maltratos que recibía de Huascar (Murúa, op. cit.: 153-164).

Huascar se identific6, por la madre, con el linaje de Hurin, renegó de su parentesco con los Hanan y del linaje de los Yupanqui. Se denominó como perteneciente a Hurin y le quitó los bienes al sol "porque los del pueblo de Guascar do el nació eran del apellido Hurin Cuzco que él lo era ansi mismo y que de allf adelante le nombrasen de Hurin Cuzco, porque Atahuallpa era de Hanan Cuzco y de la línea de Inga Yupanqui, que él no quisiera ser de esa línea sino de Hurin Cuzco... él pensaba matar a Atahuallpa y a todos sus deudos y de su linaje que eran de Hanan Cuzco y hacer de nuevo linaje de Hurin Cuzco" (Betanzos, op. cit.: 207-210).
Este inca abandonó el Cusco -que representaba el centro del poder de los Yupanqui-, y se fue a establecer a Calca, donde fundó un pueblo. Comportamiento que recuerda al de Viracocha cuando se refugio encima de Calca, en Xaquijaguana, e hizo nuevo pueblo allí, después de la usurpación de Pachacutec (Ibid: 211).

No sólo se mudó Huascar a ese lugar, sino que igualmente atac6 a la iglesia fundada por los Hanan, despojando al templo del sol de sus bienes. "Mandó que quitasen las tierras de coca y maíz al sol y a los demás bultus de los señores muertos y las de su padre Guayna Capac y las aplicó para sí" (Ibid: 207). Del mismo modo, puso a nobles de Hurin en los cargos estatales más relevantes, desplazando a los de Hanan: Así desconoció la autoridad militar de Cuxi Yupanqui, su primo hermano de padre, representante de ese linaje y que había sido nombrado por Guayna Capac como jefe militar y encargado del ídolo de las batallas. En su lugar, puso a Hango, un señor de los que tenía en Calca (Ibid: 211). También nombró en las acciones contra su hermano a un primo suyo de madre, Quilisca Auqui, perteneciente a una de las antiguas familias de Hurin.

Atahuallpa era hijo de Guayna Capac con Palla Coca, una prima segunda suya, bisnieta de Inga Yupanqui e hija de Llapcho, un nieto de Inga Yupanqui y una señora de Anta. No era pues hijo de señora y deuda de inca sino de un descendiente del linaje de los Yupanqui (Capac Ayllo) con una señora "Guaccha concha". De acuerdo a las normas de sucesión, él no tenía iguales derechos en cuanto a heredar el gobierno del estado frente a su hermano Huascar, "hijo de mujer principal", pero pertenecía al linaje de los Yupanqui y representó los intereses de ese linaje en el enfrentamiento por el poder del imperio incaico. Al principio, él mismo reconoció, a la muerte de su padre, según narran Betanzos y Sarmiento de Gamboa, el derecho de Huascar a la sucesión. Sin embargo, alentado por los antiguos y nuevos "Hanan", fortalecidos mediante las conquistas en el área andina del norte, Atahuallpa decidio luchar contra Huascar y el poder tradicional del Cusco, para convertirse en el nuevo Pachacutec, que cambiaría el mundo. Recibió la borla en Quito de manos del representante de la panaca de los Yupanqui, Yamque Yupanqui, y habríase casado con la hermana de éste, Cuxirimay Ocllo, legitimando su pertenecia a ese linaje.

De no haber sido vencido Atahuallpa por los españoles, el asiento del nuevo poder habría estado en la sierra del Ecuador, adonde igualmente trasladaría los tradicionales linajes para reconstruir la sociedad señorial en su nueva capital. Betanzos ha mencionado que el inca planeaba fundar un nuevo Cusco e hizo llevar a los señores o nobleza cusqueña para allá, tal como hiciera Pachacutec cuando instituyó el nuevo orden, respetando a las casas nobles existentes. ¿Habríase repetido 
nuevamente el enlace entre los Hanan venidos del Cusco y los Hurin del territorio conquistado?.

\section{CONCLUSIONES}

La oposición entre Hanan y Hurin fue tradicional a las sociedades andinas de la sierra; se vincula con la distinción entre pobladores de valle y de altura, con la de género y con la posesión de territorios: lo masculino fue identificado con los advenedizos, los conquistadores; lo femenino, con las hijas de los dueños de las tierras, los invadidos.

Esta distinción estuvo imbricada en diversos aspectos de la organización social, económica, política y religiosa.

Pachacutec representaría a uno de los últimos grupos advenedizos establecidos en el valle del Cusco. Las relaciones entre Hanan y Hurin no habían alcanzado el equilibrio cuando se produjo el enfrentamiento entre Huascar y Atahualpa.

La mujer ocupó una posición importante en la sociedad de clases, vinculada con la tierra y la posesión territorial. Ubicaba socialmente al individuo.

\section{BIBLIOGRAFIA}

ACOSTA, José de

[1550] Historia Natural y Moral de Las Indias.

1987 Ed. de J. A. Franch. Crónicas de América 34 Historia 16.

ARRIAGA, Pablo J. de

[1621] La Extirpación de la Idolatría en el Perú.

1920 En: Colección de Libros y Documentos Referentes a la Historia del Perú, t.I, Lima.

BERTONIO, Ludovico

[1612] Vocabulario de la lengua aymara.

1965 Edición Facsimilar. La Paz, Bolivia.

BETANZOS, Juan de

[1551] Suma y Narración de los Incas. Transcripción, 1987 notas y prólogo por María del Carmen Rubio, Madrid: Ediciones Atlas.

CIEZA DE LEON, Pedro de

[1550] La Crónica del Perú. Espasa Calpe S.A.

1962 Madrid.

\section{COBO, Fray Bernabé}

[1653] Historia del Nuevo Mundo. Biblioteca de

1956 Autores Españoles, tomos XVI y XCII, Ediciones Atlas, Madrid.
DUVIOLS, Pierre

1973 "Huari y Llacuaz. Agricultores y Pastores. Un Dualismo Prehispánico de Oposición y Complementariedad. En: Revista del Museo Nacional T. XXXIX: 153-191.

1986

Cultura Andina y Represión, Procesos y Visitas de Idolatrías y Hechicerías, Cajatambo, Siglo XVII, Cuzco. Centro de Estudios Rurales Andinos Bartolomé de Las Casas.

ESPINOZAS., Waldemar

1978 "Las Mujeres Secundarias de Huayna Capac: dos Casos de Señorialismo Feudal en el Imperio Inca" En: Revista del Museo Nacioral, T. XL:247-298.

\section{GARCILASO DELA VEGA, Inca}

[1609] Los Comentarios Reales de los Incas,

1943 Colección de Historiadores Clásicos del Perú, T.I, Librería e Imprenta Gil, Lima.

GUAMÁN POMA DE AYALA, Felipe

[1613] Nueva Crónica y Buen Gobierno. Edición

1936 Facsimilar, París.

\section{HERNÁNDEZ PRINCIPE, Rodrigo}

[1621-22] "Mitología Andina, Idolatría en Recuay".En:

1923 Revista Inca, Organo del Museo de Arqueología de la Universidad de San Marcos, vol.1, no. 1:25-68.

LYON, Patricia

1978 "Female Supernaturals in Ancient Peru". En: Nawpa Pacha, $N^{\circ}$. 16: 95-144. Institute of Andean Studies. Berkeley, California.

\section{MITCHELL, William}

1981 "La Agricultura de Riego en la Sierra Central de los Andes; Implicaciones para el Desarrollo del estado". En: La Tecnología en el Mundo Andino. Editado por $\mathrm{H}$. Lechtman y A. Soldi. Universidad Nacional Autónoma de México.

MURÚA, Fray Martín de

[1600y Historia General del Perú. Edición de M. Ba-

1611] llesteros, Crónicas de América 35. Historia

198716.

PACHACUTI YAMQUI, Joan Santa Cruz

[1613] Relación de Antigüedades deste Reyno del

1927 Perú.Colección de Libros y Documentos Referentes a la Historia del Perú, T. DX, Imprenta y Librería San Marti, Lima.

\section{ROSTWOROWSKI, María}

1988 Historia del Tahuantinsuyu. IEP, Lima. 


\section{SARMIENTO DE GAMBOA, Pedro}

[1572] Historia de los Incas. Emecé Editores S.A, 1943 Buenos Aires.

SILVERBLATT, Irene

1978 "Principios de Organización Femenina en el Tahuantinsuyu. En: Revista del Museo Nacional, T. XLII:299-340.

TAYLOR, Gerald

1987 Ritos y Tradiciones de Huarochiri del Siglo
XVII. Instituto de Estudios Peruanos-Instituto Francés de Estudios Andinos.

\section{ZUIDEMA, Tom}

1980 "El Sistema de Parentesco Incaico: Una Nueva Visión Teórica. En: Parentesco y Matrimonio en los Andes. Editores: E. Mayer y R. Bolton. Pontificia Universidad Católica del Perú.

1991 La Civilización Inca en el Cuzco. Fondo de Cultura Económica,México. 